\title{
Intensified aridity in the Qaidam Basin during the middle Miocene: constraints from ostracod, stable isotope and weathering records
}

\begin{tabular}{|r|l|}
\hline Journal: & Canadian Journal of Earth Sciences \\
\hline Manuscript ID & cjes-2016-0052.R2 \\
\hline Danuscript Type: & Article \\
\hline Complete List of Authors: & $\begin{array}{l}\text { Song, Bowen; China University of Geosciences, Wuhan, Institute of } \\
\text { Geological Survey,State Key Laboratory of Biogeology and Environmental } \\
\text { Geology } \\
\text { Ji, Junliang; China University of Geosciences, Wuhan, State Key Laboratory } \\
\text { of Biogeology and Environmental Geology,Faculty of Earth Sciences } \\
\text { Wang, Chaowen; China University of Geosciences, Wuhan, Gemological } \\
\text { Institute } \\
\text { Xu, Yadong; China University of Geosciences, Faculty of Earth Science } \\
\text { Zhang, Kexin; China University of Geosciences, Faculty of Earth Science }\end{array}$ \\
\hline Keyword: & \begin{tabular}{l} 
ostracod, stable isotopes, Qaidam Basin, Central Asia aridification \\
\hline
\end{tabular} \\
\hline \multicolumn{2}{|c}{} \\
\hline
\end{tabular}




\title{
Intensified aridity in the Qaidam Basin during the middle Miocene:
} constraints from ostracod, stable isotope and weathering records

\author{
Bowen Song ${ }^{1,2}$, Junliang $\mathrm{Ji}^{2,3}$,Chaowen Wang ${ }^{4}$, Yadong $\mathrm{Xu}^{2,3}$, Kexin Zhang ${ }^{2,3^{*}}$, \\ ${ }^{1}$ Institute of Geological Survey, China University of Geosciences, Wuhan, 430074,
}

China.

${ }^{2}$ State Key Laboratory of Biogeology and Environmental Geology, China University of Geosciences, Wuhan, 430074, China.

${ }^{3}$ Faculty of Earth Sciences, China University of Geosciences, Wuhan 430074, China.

${ }^{4}$ Gemological Institute, China University of Geosciences, Wuhan 430074, China.

\section{*Corresponding author:}

Kexin Zhang

State Key Laboratory of Biogeology and Environmental Geology,

Faculty of Earth Sciences,

China University of Geosciences, Wuhan, 430074, China

E-mail: kx_zhang@cug.edu.cn Tel: +008618986291730. 
Abstract: The thick and continuous Cenozoic successions in the Qaidam Basin provide an excellent paleoclimate archive. Here, we focus on the ostracod fauna, stable isotope records, and paleoweathering indices from a well-dated Cenozoic sedimentary section in the Qaidam Basin, to develop an understanding of the middle Miocene aridification in central Asia. Microfossil analyses suggest that the ostracod species diversity suddenly decreased after 13.3 Ma, and that the dominant ostracod genus shifted from Ilyocypris to Cyprideis. Stable isotope data from ostracod valves display abrupt positive shifts of 3.75\% in $\delta^{18} \mathrm{O}$ values and 5.28\% in $\delta^{13} \mathrm{C}$ values since 13.3 Ma. The Chemical Index of Weathering (CIW) and $\mathrm{K} / \mathrm{Na}$ ratios decrease markedly after 13.3 Ma, reflecting a significant decrease in chemical weathering intensity. These combined and consistent observations suggest that the Qaidam Basin has experienced increased aridification since 13.3 Ma. The dating was obtained direct from previous magnetostratigraphic studies and can be accurately correlated with global climate evolution and regional tectonic events. A comparing of these results with global paleoclimatic records and previous geologic studies of the Tibetan Plateau, revealed that global cooling rather than uplift of the Tibetan Plateau played a key role in the drying of the Qaidam Basin at approximately $13 \mathrm{Ma}$.

Keywords: ostracod, stable isotopes, Qaidam Basin, Central Asia aridification 


\section{Introduction}

Central Asia is sensitive to regional and global climate changes (Liu 1985; An et al. 2001; Guo et al. 2002; Bosboom et al. 2011; Xiao et al. 2012; Clift et al. 2014). Over the previou few decades, numerous studies have argued stepwise enhancement of aridity in Central Asia during the Cenozoic. However, the details of this intensified aridification and its forcing mechanisms are still controversial, especially during the Miocene (Guo et al. 2002; Dettman et al. 2003; Jiang et al. 2008; Kent-Corson et al. 2009; Li et al. 2011; Miao et al. 2011, 2012; Hough et al. 2011; Zhuang et al. 2011a; Tang et al. 2011, 2013; Zhang et al. 2013; Song et al. 2014; Zhuang et al. 2014; Zhang et al. 2015; Sun et al. 2015). The main driving forces of aridification in Central Asia comprise uplift of the Tibetan Plateau, global cooling, and retreat of the Paratethys Sea (Kutzbach 1989; Ruddiman et al. 1989; Raymo and Ruddiman 1992; Ramstein et al. 1997; Rea et al. 1998; An et al. 2001; Guo et al. 2002; Bosboom et al. 2011; Miao et al. 2011, 2012).

The Qaidam Basin provides unique insight into paleoclimatic change and its relationship with global change and uplift of the Tibetan Plateau (Fang et al. 2007; Zhuang et al. 2011b; Wang et al. 2013; Song et al. 2013; Liu et al. 2014). In this study, we focus on a 480 m-thick sedimentary sequence, that has been magnetostraigraphically dated to the span of $\sim 15 \mathrm{Ma}$ to $12.1 \mathrm{Ma}$, and perform comprehensive analyses of ostracod fauna, stable isotopes of ostracod valves, and whole-rock geochemistry.

Ostracods are micro-crustaceans with laterally compressed bodies enclosed in a 
low-magnesium calcite carapace comprising two dorsally articulated valves (De Deckker and Forester 1988). Ostracod assemblages, abundance, and diversity are controlled by various environmental factors, including habitat and water composition

(Forester 1986; De Deckker and Forester 1988; Von Grafenstein et al. 1992). Because ostracods precipitate their calcitic valves directly from lake water (Turpen and Angell 1971), their O and C isotopic signatures can provide record of previous hydrologic and climatic conditions of a lake (Holmes 1996; Holmes and Chivas 2002; Schwalb et al. 2003; Leng and Marshall 2004; Mischke and Wünnemann 2006; Keatings et al. 2010; Van Baak et al. 2012). However, no records of ostracods and their shell isotopes in the Qaidam Basin have been published thus far.

\section{Geologic setting, stratigraphy, and age control}

The Qaidam Basin is located on the northeastern margin of the Tibetan Plateau and is the largest sedimentary basin on the plateau (Fig. 1). The Qaidam Basin is bounded by the South Qilian Range on the north, the East Kunlun Range on the south, and the Aerjin Range on the west (QBGMR 1991; Huang et al. 1996). Cenozoic deposition in the Qaidam Basin began in the early Eocene, synchronous with collision of the Indian and Asian Plates (Metivier et al. 1998 ;Yin et al. 2008). Cenozoic sediments in the Qaidam Basin, more than $10 \mathrm{~km}$ total thickness, are characterized by continental sedimentary facies and consist primarily consisted of an alluvial fan, braided river, meandering river, lakeshore, shallow lake, semi-deep lake, and delta deposits. Previous studies have established a basin-scale lithostratigraphic framework for the Qaidam Basin, including the Lulehe (LLH), Xia Ganchaigou (XGCG), Shang 
Ganchaigou (SGCG), XiaYoushashan (XYSS), Shang Youshashan (SYSS), and Shizigou (SZG) formations in up-younger orders (Sun et al. 2005; Fang et al. 2007; Lu and Xiong 2009; Zhuang et al. 2011; Chang et al. 2015).

The Dahonggou (DHG) section $\left(95^{\circ} 12^{\prime} 42^{\prime \prime} \mathrm{E}, 3^{\circ} 29^{\prime} 11^{\prime \prime} \mathrm{N}\right)$ is well exposed in the southern limb of the Dahonggou anticline, at the northern margin of the Qaidam Basin (Fig. 1). This section includes $\sim 5400 \mathrm{~m}$ of continuous sediments that have been divided into six formations in an up-section sequence from the LLH to SZG formations.

A previous magnetostratigraphic study of the DHG section, including Section-k and Section-q, suggests that the SGCG Formation and XYSS Formations ranged from 34.6 to 8.5 Ma (Lu and Xiong 2009; Fig. 2). Thick green mudstone layer and characteristic folded layer in the SYSS Formation can be traced laterally in outcrops in the Dahonggou region. Based on these two marker layers, we designated them as bed 386 and bed 334 respectively in the sedimentary sequence under investigation. These two marker layers enabled us to effectively correlate the sequence that we studied (beds 334-386) with Section-k reported by Lu and Xiong (2009; Fig. 3). Thus, we can bracket the depositional age of the sedimentary sequence as $\sim 15.0-12.1 \mathrm{Ma}$.

\section{Sedimentary facies of the studied section}

In this study, we focus mainly on a $\sim 480$ m-thick sequence containing abundant ostracod fossils in the lower part of the SYSS Formation (Fig. 2). This sequence can be divided into two parts. The lower part (beds 335-366) is composed primarily mudstone and silty mudstone interbedded with sandstones lenses, all of which are 
interpreted as having been deposited in a shallow lake (Fig. 2). The alternating sandstone and mudstones of meter to decimeter scales indicate short-term fluctuations in the lake level. The upper part (beds 367-386) consists of interbedded sandstone and mudstone that likely were deposited on a subaqueous delta-front and prodelta slope (Elliott 1989; Fig. 2). Medium to coarse sandstone with plane- parallel laminated and planar cross-bedding are interpreted as mouth-bar deposits formed on the proximal delta-front (Miall 1996).

\section{Materials and methods}

\subsection{Ostracod analyses}

Biostratigraphical analysis was performed on 186 ostracod samples from the lower part of the SYSS Formation. Sediment samples with one centimeter thick were disaggregated in $8 \% \mathrm{H}_{2} \mathrm{O}_{2}$ for $48 \mathrm{~h}$ and were sieved using distilled water and standard sieves at mesh sizes of $0.1 \mathrm{~mm}$ and $0.25 \mathrm{~mm}$. The fractions retained in the sieves were rinsed with distilled water and were dried at $35{ }^{\circ} \mathrm{C}$ in an oven for at least $48 \mathrm{~h}$. The ostracod valves were extracted from the sieve residues using a brush under a binocular microscope with a magnification of 10. Taxonomic identification and ecological inferences were based on the following papers :Huang et al. (1982), Huang (1984), Exploration and Development Research Institute, Qinghai Petroleum Administration and Nanjing Institute of Geology and Palaeontology, Chinese Academy of Sciences (1988), Meisch (2000), Hou et al. (2002), Hou and Gou (2007), Frenzel and Boomer (2005), Yang et al. (2006) and Viehberg et al.(2008). The criterion for recognizing ostracods in this study was based on Sylvester-Bradley (1961). 
Owing to the absence of a single species with continuous occurrence in the entire section, the stable $\mathrm{O}$ and $\mathrm{C}$ isotopes in the valves of three ostracod species (Ilyocypris gibba, Candoniella albicans, and Cyprideis torosa ) were analyzed. Thus, ostracods from 25 samples were selected for $\mathrm{C}$ and $\mathrm{O}$ isotope analyses. To avoid errors due to diagenetic effects, all analyzed valves were selected from those in pristine condition (Keatings et al. 2002). The preparation of the samples and $\mathrm{C}$ and $\mathrm{O}$ isotope analyses were performed at the Laboratory of Marine Geology, Tongji University, Shanghai, China. The ostracod valves were rinsed three times for 5-10 s with ethanol (X99.7\%) in a $40-\mathrm{kHz}$ ultrasonic bath. These samples were dried at $60^{\circ} \mathrm{C}$ for $5 \mathrm{~h}$ and were placed in a sample vial in a Finnigan automatic carbonate device (Kiel III). The samples were reacted with orthophosphoric acid at $70^{\circ} \mathrm{C}$ to generate $\mathrm{CO}_{2}$, and transferred to a Finnigan MAT253 mass spectrometer for measurements. The resulting data are reported using the $\delta \%$ notation relative to the VPDB standard. The precision was regularly verified against the Chinese GBW04405 carbonate standard and international NBS19 standard. The standard deviation was $0.04 \%$ for $\delta^{13} \mathrm{C}$ and $0.07 \%$ for $\delta^{18} \mathrm{O}$.

\subsection{Bulk major chemical elements}

Weathering indices based on the ratio of a group of mobile oxides to one or more immobile oxides were used to reconstruct changes induced by weathering (Nesbitt and Young 1982). The chemical index of alteration (CIA) was suggested by Nesbitt and Young $(1982,1984)$ as a method of quantifying the degree of chemical weathering to which rocks have been subjected. This index was used as a general 
guide regarding the degree of chemical weathering in the source regions. Because diagenesis may affect the CIA value, source weathering and elemental redistribution during diagenesis were assessed by using the Chemical Index of Weathering (CIW= $\left[\mathrm{Al}_{2} \mathrm{O}_{3} /\left(\mathrm{Al}_{2} \mathrm{O}_{3}+\mathrm{CaO} *+\mathrm{Na}_{2} \mathrm{O}\right)\right] \times 100 ;$ Harnois et al. 1988). In the preceding equation, element abundances are expressed as molar proportions, and $\mathrm{CaO} *$ represents the $\mathrm{Ca}$ in the silicate (non-carbonate) mineral fraction only. Following McLennan (1993), we used the molar proportion of $\mathrm{Na}_{2} \mathrm{O}$ rather than that of $\mathrm{CaO}$ from the silicate fraction because limestone strata are common in the source area, i.e., the South Qilian terranes (QBGMR 1991; Zhuang et al. 2011b).

Owing to the preferential decomposition of plagioclase with respect to potassiumfeldspar during silicate weathering, the $\mathrm{K}_{2} \mathrm{O} / \mathrm{Na}_{2} \mathrm{O}$ (hereafter abbreviated as $\mathrm{K} / \mathrm{Na}$ ) ratio increases as a result of rapid loss of $\mathrm{Na}^{+}$in the plagioclase (Nesbitt et al. 1980, 1996). Thus, in this study, the CIW index and K/Na ratio were used to detect variations in chemical weathering in the sedimentary sequence. Fifty fresh whole-rock samples were collected from the sequence, and chemical analyses were performed at the Laboratory of Rock and Mineral Analysis Test Center of the Chinese Ministry of Land, Wuhan, China. Major elements $\left(\mathrm{Na}_{2} \mathrm{O}, \mathrm{MgO}, \mathrm{Al}_{2} \mathrm{O}_{3}, \mathrm{SiO}_{2}, \mathrm{P}_{2} \mathrm{O}_{5}, \mathrm{~K}_{2} \mathrm{O}, \mathrm{CaO}\right.$, $\mathrm{TiO}_{2}, \mathrm{MnO}, \mathrm{Fe}_{2} \mathrm{O}_{3}, \mathrm{FeO}$, and $\mathrm{H}_{2} \mathrm{O}^{+}$) were analyzed by using a Magix Pro PW2440 X-ray fluorescence (XRF) spectrometer. The resulting data are expressed in percentages, and all errors were within $1 \%$ except for $\mathrm{MgO}$, at $1.9 \%$. The concentrations of the major elements are listed in Table 1.

\section{Results}




\subsection{Ostracod fauna}

The section contains abundant ostracods and yielded 18791 valves were recovered from 57 samples. Eighteen species from 9 genera were identified (Figs. 4, 5). The Ilyocypris and Cyprideis genera dominate and account for $51.7 \%$ and $40.4 \%$ of the specimens in the sequence, respectively. The discovery of numerous Cyprideis species in bed 351 and above strongly supports the middle Miocene age of the sequence (Van den Bold 1976; Sun et al. 1999; Yang et al. 2000; Yang et al. 2006; Meisch 2000; Ligios and Gliozzi 2012).

The ostracod fauna can be subdivided into two assemblages: an Ilyocypris. cf. gibba-I. bradyi-Candoniella albicans-Leucocythere dorsotuberosa-Cyprinotus salinus assemblage and a Cyprideis torosa-Cyprideis Subtera-Cyprideis $\mathrm{cf}$. subeboliangensis assemblage.

Assemblage I is composed of sixteen species in nine genera and is characterized by relatively high diversity, and includes Ilyocypris cf. gibba, Ilyocypris bradyi, Candoniella albicans, Leucocythere dorsotuberosa and Cyprinotus salinus. In addition, Cycloypris glacialis, Candoniella foliaceus, Candoniella suzini, Leucocythere mirabilis, Leucocytherella hyalina, Cyprinotus gibbus, Cypris acuta, Potamocypris longisetosa, Potamocypris lenghuensis, Cyprideis torosa and Cyprideis Subtera are present in this assemblage (Figs. 4, 5). They are distributed in the lower part of the sequence (Unit 1, beds 335-351).

Assemblage II is composed of five species in two genera, including Cyprideis torosa, Cyprideis Subtera, Cyprideis cf. subeboliangensis, Cyprideis sp. and Cypris 
acuta (Figs. 4, 5). Compared with Assemblage I, the ostracod diversity is greatly reduced and it is dominated by Cyprideis torosa, which is typically abundant in coastal marine, lagoonal, and saline inland waters (Meisch 2000; Frenzel and Boomer 2005; Viehberg et al. 2008; Gross et al. 2008). These ostracods are distributed in the upper part of the sequence (Unit 2, above bed 351; Fig. 4).

\subsection{Stable isotopes in the ostracod valves}

The ostracods calcitic valves yield a wide range of stable isotope values. Their $\delta^{13} \mathrm{C}$ values range from $-9.9 \%$ to $-0.3 \%$, and their $\delta^{18} \mathrm{O}$ values range from $-12.6 \%$ to $-5.9 \%$ (Table 2). To assess the species-specific offsets due to disequilibrium or so-called "vital effects", we normalized the $\delta^{18} \mathrm{O}$ values of the three analyzed species by subtracting the vital-offset values relative to the theoretical inorganic calcite in equilibrium (Table.2), including 2.0\%o for C. torosa (Marco-Barba et al. 2012), approximately 3.0\%o for C. albicans (Decrouy et al. 2011), and 3.9\%o for I. bradyi (Belis and Ariztegui 2004; Anadón et al. 2012).

Variations in the stable isotope values from the ostracod valves correlate with the division of the sequence into two major units based on species data (Fig. 6). In the lower part, the $\delta^{18} \mathrm{O}$ and $\delta^{13} \mathrm{C}$ values are generally lower and vary within a broad range. Above bed 351 (after 13.3 Ma), the $\delta^{18} \mathrm{O}$ and $\delta^{13} \mathrm{C}$ values are much higher and cluster within a much narrower range. In the plots of $\delta^{18} \mathrm{O}$ and $\delta^{13} \mathrm{C}$, two groups can be differentiated based on the stratigraphic positions of the samples (Fig. 6). Group 1, which corresponds to Unit 1 , displays $\delta^{13} \mathrm{C}$ values between $-9.9 \%$ and $-4.0 \%$ with a mean of $-6.53 \%$ and $\delta^{18} \mathrm{O}$ values between $-15.6 \%$ and $-10.0 \%$ with a mean of 
$-12.22 \%$. Group 2, which corresponds to Unit 2, displays $\delta^{13} \mathrm{C}$ values between -3.3 and $-0.3 \%$ with a mean of $-1.25 \%$ and $\delta^{18} \mathrm{O}$ values between -9.2 and $-7.9 \%$ with a mean of $-8.47 \%$. The relatively large variations in the isotopic signatures of $\delta^{18} \mathrm{O}$ and $\delta^{13} \mathrm{C}$ suggest that significant changes occurred in the isotopic compositions of the lake that the ostracods inhabited.

\subsection{Chemical weathering intensity}

The bulk major chemical element ratios ( $\mathrm{CIW}$ and $\mathrm{K} / \mathrm{Na}$ ) show characteristic trends in the time intervals of beds 335-386, allowing for a subdivision of the sequence into two major units (Fig. 7b). In Unit 1, both the CIW and K/Na ratios are high, suggesting strong chemical weathering intensity in the study area. In contrast, both the $\mathrm{CIW}$ and $\mathrm{K} / \mathrm{Na}$ ratios are decreased significantly in Unit 2 compared with those in Unit 1 (Fig. 7b)

\section{Discussion}

\subsection{Factors controlling $\delta^{18} \mathrm{O}$ and $\delta^{13} \mathrm{C}$ variations}

The $\mathrm{O}$ isotope record of calcitic ostracod valves that precipitate in equilibrium with evaporating water can be used to evaluate long-term changes in the paleohydrologic parameters of lakes (Dutkiewicz et al. 2000). In addition to the $\delta^{18} \mathrm{O}$ ratio of the water, the temperature also affects the $\delta^{18} \mathrm{O}$ ratio of authigenic carbonates, and, therefore, ostracod valves (Stuiver 1970; Lister et al. 1991; Holmes 1996; von Grafenstein et al. 1999; Keatings et al. 2002; Leng and Marshall 2004; Liu et al. 2009).

Previous studies have suggested that temperature fluctuations cause a change in 
$\delta^{18} \mathrm{O}$ of approximately $0.35 \% /{ }^{\circ} \mathrm{C}$ (Craig 1965; O’Neil et al. 1969; Rozanski et al. 1993; Zhuang et al. 2011a; Wang et al. 2012). In this study, the 3.75\% positive shift from Unit 1 to Unit 2 would require a temperature increase of $\sim 10.7^{\circ} \mathrm{C}$ (Fig. 7a), which is unlikely to have occurred given the gradual global cooling in the late Cenozoic (Zachos et al. 2001). The observed variations in average $\delta^{18} \mathrm{O}$ values, ranging from $-12.22 \%$ to $-8.47 \%$, are much larger than the likely water temperature variations. Thus, a change in temperature cannot explain this major positive $\delta^{18} \mathrm{O}$ shift. Talbot (1990) suggested that covariation between $\mathrm{C}$ and O isotopes is an indicator of residence time within a lake. Closed lakes exhibit a high degree of covariation of $\delta^{18} \mathrm{O}$ and $\delta^{13} \mathrm{C}$ values, whereas open lakes exhibit little or no covariation. The poor correlation between $\delta^{18} \mathrm{O}$ and $\delta^{13} \mathrm{C}$ values in Unit $1\left(\mathrm{r}^{2}=0.0365, \mathrm{n}=17\right)$ suggests an open lake system.

Units 1 displays a wide range of $\delta^{18} \mathrm{O}$ and $\delta^{13} \mathrm{C}$ values (Fig. 7a), indicating abroad range of isotopic compositions where the ostracods lived. This corresponds to a relatively broad range of precipitation-evaporation $(\mathrm{P} / \mathrm{E})$ ratios. In contrast, the high correlation between $\delta^{18} \mathrm{O}$ and $\delta^{13} \mathrm{C}$ values $\left(\mathrm{r}^{2}=0.6056, \mathrm{n}=8\right)$ in Unit 2 is a typical feature of primary carbonates from hydrologically closed lakes with long residence times (Fig. 6). This difference between Units 1 and 2 suggests a remarkable change in the lake system from open to closed hydrologic conditions. In addition, higher salinities in Unit 2 are also suggested by the abundance of Cyprideis, which typically inhabits brackish water (Figs. 4, 5). Thus, we argue that the increase in correlation between the $\mathrm{O}$ and $\mathrm{C}$ isotope values in the ostracod valves and the clear increase in 
$\delta^{18} \mathrm{O}$ values were likely caused by a shift to more arid conditions and lower P/E ratios at 13.3 Ma.

The $\delta^{13} \mathrm{C}$ values of ostracod valves are primarily controlled by the $\delta^{13} \mathrm{C}$ of dissolved inorganic C (DIC) in a lake (von Grafenstein et al. 1999). DIC is controlled by the isotopic composition of inflowing waters, $\mathrm{CO}_{2}$ exchange between the atmosphere and lake, and photosynthesis and respiration of aquatic plants in a lake (Deines et al. 1974; Anadón et al. 1994; Ortiz et al. 2006; Keatings et al. 2010; Li et al. 2012). Moreover, drier conditions can also lead to lower lake levels and changes in aqueous $\mathrm{CO}_{2}$ concentrations as a result of increased salinity, which reduces the concentration of dissolved $\mathrm{CO}_{2}$ and raises $\delta^{13} \mathrm{C}$ to more positive values (Leng and Marshall 2004). Therefore, in this study, the major shift of $\delta^{13} \mathrm{C}$ values from $-6.53 \%$ in Unit 1 to $-1.25 \%$ in Unit 2 suggests a decreasing $\mathrm{P} / \mathrm{E}$ ratio in the water body and an increase residence time in the lake (Fig. 7a).

\subsection{Paleohydrologic variations in the lake}

Lakes in arid and semi-arid regions are particularly sensitive to changes in hydrology (De Deckker 1983; Liu et al. 2009; Keatings et al. 2010). The distributions of ostracods in water bodies are largely controlled by the salinity and, more specifically by the solute composition of the water (Neale 1988; Mezquita et al. 2005; Mischke et al. 2010, 2012). The concentrations of ions in a lake control the abundance of several ostracod species, whereas their presence or absence is controlled primarily by the salinity (Boomer and Eisenhauer 2002). Forester (1986) suggested that

freshwater ostracods dominate the assemblages in waters that contain both $\mathrm{Ca}^{2+}$ and 
$\mathrm{HCO}_{3}{ }^{-}$, whereas $\mathrm{Na}^{+}$(plus $\mathrm{K}^{+}$) is generally the dominant cation in most saline lakes. The distribution of ostracods in the studied sequence reveals a major shift from domination by Ilyocypris in Unit 1 to domination by Cyprideis dominated in Unit 2 (Figs. 4, 5). These two ostracod genera have remarkably different solute preferences. Mischke et al. (2012) suggested that Ilyocypris does not demonstrate a preference for dominant host water cations and anions. In contrast, Cyprideis torosa prefers water with a $\mathrm{Na}^{+}-\mathrm{Cl}^{-}$composition (Mezquita et al. 1999; Anadón et al. 2009, 2012; Mischke et al. 2012). Thus, the shift in predominance from Ilyocypris to Cyprideis indicates a hydrochemical change in the lake, which correlates well with the rapid increase in evaporite minerals such as gypsum and halite at the bottom of Unit 2 (Fig. 7d).

Furthermore, the conglomerates initially appear in the lowermost part of unit 2 and become more abundant in upward section, indicating a decline in the lake level.

\subsection{Paleoenvironmental evolution}

The climate proxies in the studied sequence of the DHG section display a twofold division: Stage I ( 15.0 to13.3Ma) and Stage II (13.3 to $\sim 12.1 \mathrm{Ma})$.

Stage I ( 15.0 to $13.3 \mathrm{Ma})$

Stage I corresponds to Unit 1 and is characterized by relatively low mean values of $\delta^{18} \mathrm{O}$ and $\delta^{13} \mathrm{C}$. Based on the discussion presented in the preceding section, the low values of $\delta^{18} \mathrm{O}$ and $\delta^{13} \mathrm{C}$ in Unit 1 are related to a period of lake expansion in a humid climate. Furthermore, the $\mathrm{O}$ and $\mathrm{C}$ stable isotopic compositions in Unit 1 do not display covariance, possessing an $\mathrm{R}^{2}$ value of 0.0365 (Fig. 6). This is likely associated with a low residence time and open-system lacustrine dynamics (Talbot 1990). 
Moreover, the dominance of freshwater-brackish species in this unit suggests generally wetter conditions (Figs. 4, 5). In addition, the CIW and K/Na values in this stage are characteristically high. This suggests strong chemical weathering in the study area, which also implies generally wetter climate conditions (Fig. 7). Stage II (13.3 to $12.1 \mathrm{Ma})$

Stage II corresponds to Unit 2, which is marked by conglomerates that initially appear in the lowermost part of Unit 2 and become more frequent upward, indicating a fall in the lake level. Both the $\delta^{18} \mathrm{O}$ and $\delta^{13} \mathrm{C}$ values in this unit are characteristically high, with a narrow distribution and strong correlations (Figs. 6, 7), which are typical features of a closed lake system with distinct changes in the $\mathrm{P} / \mathrm{E}$ ratio (Talbot 1990; Anadón et al. 2009). Moreover, Unit 2 contains markedly lower ostracod diversity than Unit 1 and is dominated by the high-salinity the saline species Cyprideis torosa (Fig. 4). This indicates a dramatic transition from a freshwater-brackish environment to a saline environment, i.e., a significant increase in lake salinity. In addition, evaporite minerals, gypsum and halite, are also much more abundant in this unit than in Unit 1. Furthermore, the CIW and K/Na ratios in Stage II are marked by significant decreases compared with those in Stage I. Previous studies have suggested that Ti/Al ratios can be used to identify sediments and rocks of originally uniform composition (Wintsch and Kvale 1994; Young and Nesbitt 1998). The ratio of $\mathrm{TiO}_{2} / \mathrm{Al}_{2} \mathrm{O}_{3}$ (abbreviated as $\mathrm{Ti} / \mathrm{Al}$ ) is essentially constant throughout the succession, although with slight variations (Fig. 7c), indicating stable source areas during deposition. These elements were likely not affected by any changes in provenance. Thus, a 
comprehensive review of these two proxies revealed a significant decrease in the chemical weathering intensity from $\sim 15-13.3$ Ma to $\sim 13.3-12.1$ Ma. Overall, the above lines of evidence demonstrate that the Qaidam Basin experienced increased aridification after 13.3 Ma.

\subsection{Extensive aridification of inland Asia at approximately 13 Ma}

The extensive aridification of inland Asia in the middle Miocene ( $\sim 13 \mathrm{Ma})$ has been documented in several basins in northwestern China (Fig. 8). (1) In the Junggar Basin, the palynological record suggests that dry conditions peaked at $13.5 \mathrm{Ma}$ and lasted throughout the late Miocene and early Pliocene (Tang et al. 2011) and that eolian deposition started at 13.5 Ma (Sun et al. 2010). (2) In the Jiuxi and Qaidam basins, the palynological assemblage is dominated by steppe vegetation such as Artemisia and Chenopodiaceae (Ma et al. 2005). (3)The O and C isotopic compositions of carbonates, leaves, and fossil tooth enamel in the Linxia, Qaidam, and Tarim basins shifted to markedly positive values at approximately $13-11 \mathrm{Ma}$, suggesting extensive aridification of the northeastern Tibetan Plateau (Dettman et al. 2003; Graham et al. 2005; Wang and Deng 2005; Kent-Corson et al. 2009; Hough et al. 2011; Zhuang et al. 2011a). Combined, these climate proxies obtained from basins in northwestern China clearly indicate the intensification of aridification in the middle Miocene $(\sim 13 \mathrm{Ma})$.

As noted above, the onset of Asian aridification has been variably associated with global cooling, uplift of the Tibetan Plateau, and westward retreat of the Para-tethys Sea. Recent studies indicate that the last major withdrawal of the Paratethys from the 
Tarim Basin occurred before 13 Ma (37 Ma, e.g., Bosboom et al. 2011; 34Ma, Wang et al. 2014), suggesting that the retreat of the Para-tethys Sea did not exert a significant effect on the aridification in the Qaidam Basin during the middle Miocene. Global cooling after $\sim 14$ Ma presumably played an important role in drying the interior of Asia by reducing the amount of water vapor in the atmosphere (Jiang and Ding 2008; Lu et al. 2010; Miao et al. 2011, 2012). The major drying event that occurred in the Qaidam Basin at 13.3 Ma coincides with global cooling trends after the middle-Miocene optimum conditions (Zachos et al. 2001, 2008). With this ongoing global cooling, evaporation from the sea and the concentration of water vapor in the atmosphere will decrease. Thus, we argue that global cooling played a key role in the drying of the Qaidam Basin at approximately 13 Ma.

The high elevation of the Tibetan Plateau would have altered the vapor transport pathways (Ruddiman and Kutzbach 1989), preventing moisture from the east and south farther into inland Asia. Several studies have suggested rapid uplift of the central and northeastern Tibetan Plateau during the middle Miocene period (Yu 1994; Coleman and Hodges 1995; Blisniuk et al. 2001; Sun et al. 2005; Clark et al. 2005; Royden et al. 2008; Lease et al. 2011; Zhuang et al. 2011b; Hough et al. 2011, 2014). However, beacuse aridification of central Asia was also recorded outside of the Tibetan Plateau, such as in the Junggar Basin (Sun et al. 2010;Tang et al. 2011; Fig. 8), we suggest that uplift of theTibetan Plateau may have been a secondary cause, along with global cooling, of the intensified aridity of the Qaidam Basin since the middle Miocene( 13Ma). 


\section{Conclusion}

Our comprehensive analyses on environmental proxies from the DHG section in the northern Qaidam Basin, including lithofacies, ostracod fauna, stable isotope records, and paleoweathering indices, enable us to reconstruct a detailed evolution of climate from $\sim 15$ to $12.1 \mathrm{Ma}$.

The obtained climate proxies in the studied sedimentary sequence of the DHG section displayed a two-step variation that occurred at $\sim 13.3 \mathrm{Ma}$. Stage I is characterized by freshwater ostracods and relatively low values of $\delta^{18} \mathrm{O}$ and $\delta^{13} \mathrm{C}$, which are related to periods of lake expansion in a humid climate. Stage II is characterized by saline water ostracods, relatively high values of $\delta^{18} \mathrm{O}$ and $\delta^{13} \mathrm{C}$, and rapid increase in evaporate minerals, indicating shrinkage of the lake and markable aridification.

This notable drying event at13.3 Ma correlates well with regional and global paleoclimatic records, suggesting that the global cooling, rather than uplift of the Tibetan Plateau played a key role in drying of Qaidam basin.

\section{Acknowledgements.}

This work is funded by the Foundation of the Geological Survey of China (No.12120 11121261), the Fundamental Research Funds of the Central Universities, China University of Geosciences, Wuhan (No. CUGL140831), the China Postdoctoral Science Foundation (No.2014M552109, 2015M582301), and the State Key Laboratory of Biogeology and Environmental Geology, China University of 
Geosciences (No. GBL11307). The authors thank Xianyin An, Liang Luo, Yuanyuan Sun, Shangsong Jiang and Jianyu Zhang for field assistance.

Appendix 1. Data table showing ostracod occurrences in the sedimentary sequence of the Dahonggou section.

\section{References}

An, Z.S., Kutzbach, J.E., Prell, W.L., Porter, S.C. 2001. Evolution of Asian monsoons and phased uplift of the Himalaya-Tibetan plateau since Late Miocene times. Nature, 411:62-66.

Anadón, P., Utrilla, R., Julià, R. 1994. Palaeoenvironmental reconstruction of a Pleistocene lacustrine sequence from faunal assemblages and ostracods shell geochemistry, Baza Basin, SE Spain. Palaeogeography, Palaeoclimatology, Palaeoecology, 111:191-205.

Anado'n, P., Gaba`s, M. 2009. Paleoenvironmental evolution of the Early Pleistocene lacustrine sequence at Barranco Leo'n archeological site (Orce, Baza Basin, Southern Spain) from stable isotopes and $\mathrm{Sr}$ and $\mathrm{Mg}$ chemistry of ostracods valves. Journal of Paleolimnology, 42: 261-279.

Anadón, P., Gliozzi, E. , Mazzini, I. 2012. Geochemical and Palaeoecological Analyses of Mid Pleistocene to Holocene Ostracods Assemblages from Valle di Castiglione (Italy): Palaeoenvironmental and Palaeoclimatic Assessment . Developments in Quaternary Sciences, 17: 217-240.

Belis, C.A., Ariztegui, D. 2004. The influence of biological and environmental factors 
on the stable isotopic composition of ostracods - the Late Pleistocene record from Lake Albano, Central Italy. Journal of Limnology, 63:219-232.

Boomer, I., Eisenhauer, G. 2002. Ostracods faunas as palaeoenvironmental indicators in marginal marine environments. Geophysical Monograph Series, 131:135-149.

Bosboom, R.E., Dupont-Nivet, G., Houben, A.J.P., Brinkhuis, H., Villa,G., Mandic, O., Stoica, M., Zachariasse,W.-J., Guo,Z., Li,C. 2011. Late Eocene sea retreat from the Tarim Basin (WestChina) and concomitant Asian paleoenvironmental change. Palaeogeography, Palaeoclimatology, Palaeoecology, 299:385-398.

Blisniuk, P.M., Hacker, B.R., Glodny, J., Ratschbacher, L., Bik, S.,Wull, Z., McWilliams, M.O. , Calvert, A. 2001. Normal faulting in central Tibet since at least 13.5 Myr ago. Nature, 412: 628-632.

Chang, H., Li, L.Y., Qiang, X.K., Garzione, C.N., Pullen, A., An, Z.S., 2015. Magnetostratigraphy of Cenozoic deposits in the western Qaidam Basin and its implication for the surface uplift of the northeastern margin of the Tibetan Plateau. Earth and Planetary Science Letters, 430:271-283.

Clark, M.K., House, M.A., Royden, L.H., Whipple, K.X., Burchfiel, B.C., Zhang, X. and Tang, W. 2005. Late Cenozoic uplift of southeastern Tibet. Geology, 33: $525-528$.

Clift, P.D., Wan, S.M., Blusztajn, J. 2014. Reconstructing chemical weathering, physical erosion and monsoon intensity since $25 \mathrm{Ma}$ in the northern South China Sea: A review of competing proxies, Earth Science Review, 130: 86-102.

Coleman, M., Hodges, K. 1995. Evidence for Tibetan plateau uplift before 14 Myr 
ago from a new minimum age for east - west extension. Nature, 374: 49-52.

Craig,H. 1965. The measurement of oxygen isotope palaeotemperatures. In: Stable Isotopes in Oceanographic Studies and Palaeotemperatures. Edited by Tongiorgi E., Pisa, Consiglio Nazionale delle Ricerche Laboratorio di Geologia Nucleare. pp.161-182.

Gross, M., Minati, K., Danielopol, D.L., Piller, W.E. 2008. Environmental changes and diversification of Cyprideis in the Late Miocene of the Styrian Basin (Lake Pannon,Austria). Senckenbergiana lethaea, 88:161-181.

Dettman, D., Fang, X.M., Garzione, C., Li, J.J. 2003. Uplift-driven climate change at $12 \mathrm{Ma}$ : a long [delta] ${ }^{18} \mathrm{O}$ record from the NE margin of the Tibetan plateau. Earth and Planetary Science Letters, 214:267-277.

De Deckker, P. 1983.Australian salt lakes: their history, chemistry, and biota - a review. Hydrobiologia, 105:231- 244.

De Deckker, P., Forester, R.M. 1988.The use of ostracodsto reconstruct continental palaeoenvironmental records. In: Ostracoda in the Earth sciences. Edited by P. De Deckker, J.P. Colin, J.P. Peypouquet. Elsevier, Amsterdam. pp.175-199.

Decrouy, L., Vennemann, T.W., Ariztegui, D. 2011. Controls on ostracods valve geochemistry: Part 2. Carbon and oxygen isotope compositions. Geochimica et Cosmochimica Acta,75:7380-7399

Deines, P., Langmuir, D., Harmon, R.S. 1974. Stable carbon isotope ratios and the existence of a gas phase in the evolution of carbonate ground waters. Geochimica et Cosmochimica Acta, 38:1147-1164. 
Dutkiewicz, A., Herczeg, A.L., Dighton, J.C. 2000. Past changes to isotopic and solute balances in a continental playa: clues from stable isotopes of lacustrine carbonates. Chemical Geology,165: 309-329.

Elliott, T., 1989. Deltaic systems and their contribution to an understanding of Basin-fill successions. In: Deltas: Sites and Traps for Fossil Fuels. Edited by M.K.G. Whateley, K.T. Pickering, Geological Society Special Publication, London. pp.3-10.

Exploration and Development Research Institute, Qinghai Petroleum Administration and Nanjing Institute of Geology and Palaeontology, Chinese Academy of Sciences. 1988. Tertiary ostracode fauna from Qaidam Basin, NW China. Nanjing University Press, Nanjing. pp.1-190

Fang, X.M., Zhang,W.L., Meng, Q.Q., Gao, J.J.,Wang, X.M., King, J., Song, C.H., Dai, S., Miao,Y.F., 2007. High-resolution magnetostratigraphy of the Neogene Huaitoutala section in the eastern Qaidam Basin on the NE Tibetan Plateau, Qinghai Province, China and its implication on tectonic uplift of the NE Tibetan Plateau. Earth and Planetary Science Letters, 258 (1):293-306.

Forester, R. M. 1986. Determination of the dissolved anion composition of ancient lakes from fossil ostracodes. Geology, 14: 796-798.

Frenzel, P., Boomer, I. 2005.The use of ostracods from marginal marine, brackish waters as bioindicators of modern and Quaternary environmental change. Palaeogeography, Palaeoclimatology, Palaeoecology, 225:68-92

Graham, S.A., Chamberlain, C.P., Yue, Y., Ritts, B.D., Hanson, A.D., Horton, 
T.W.,Waldbauer, J.R., Poage, M.A., Feng, X. 2005. Stable isotope records of Cenozoic climate and topography, Tibetan Plateau and Tarim Basin. American Journal of Science, 305:101-118.

Guo, Z.T., Ruddiman, W.F., Hao, Q.Z., Wu, H.B., Qiao, Y.S., Zhu, R.X., Peng, S.Z., Wei, J.J., Yuan, B.Y., Liu, T.S. 2002. Onset of Asian desertification by $22 \mathrm{Myr}$ ago inferred from loess deposits in China. Nature, 416:159-163.

Harnois, L. 1988. The CIW index: a new chemical index of weathering. Sedimentary Geology, 55:319-322

Holmes, J.A. 1996. Trace-element and stable-isotope geochemistry of non-marine ostracods valves in Quaternary palaeoenvironmental reconstruction. Journal of Paleolimnology, 15: 223-235

Holmes, J.A., Chivas, A.R. 2002. Ostracods shell chemistrydoverview. In:The Ostracoda: Applications in Quaternary Research. Edited by J.A. Holmes, A.R. Chivas. AGU ,Geophysical Monograph, 131. pp. 185-204.

Hou, Y.T, Gou, Y.X., Chen, D.Q. 2002. Fossil Ostracoda of China. Vol. 1, Super families Crypridacea and Darwinulidacea. Science Press, Beijing.pp.1-1090.

Hou, Y.T., Gou, Y.X., 2007. Fossils Ostracoda of China.vol. 2, Cytheracea and Cytherellidacea. Science Press, Beijing. pp.1-798.

Hough, B.G., Garzione, C.N., Wang, Z.C., Lease, R.O., Burbank, D.W., Yuan, D. 2011. Stable isotope evidence for topographic growth and Basin segmentation: implications for the evolution of the NE Tibetan Plateau. Geological Society of America Bulletin, 123:168-185. 
Hough, B.G., Garzione, C.N., Wang, Z.C., Lease, R.O.2014. Timing and spatial patterns of Basin segmentation and climate change in northeastern Tibet. Geological Society of America Special Papers, 507: SPE507-07.

Huang, B.R., Yang, H.R., You, K.Y. 1982. Pliocene and Quaternary Ostracoda from Southern and South western Xizang. Comprehensive Scientific Expedition the Tibetan Plateau, In :The Series of the Scientific Expediti onto the Tibetan Plateau, Palaeontology of Xizang (IV ). Edited by The Chinese Academy of Sciences.pp. 326-348.

Huang, B.R.,1984. Pliocene and Early Pleistocene Ostracoda from Gonghe Basin, Qinghai. Memoirs of Nanjing Institute of Geology and Palaeontology, Science Press, Beijing, 19. pp.1-23.

Huang, H.C., Huang, Q.H., Ma, S. 1996. Geology of Qaidam Basin and Its Petroleum Prediction. Geological Publishing House, Beijing. pp.1-257.

Jiang, H.C., Ding, Z.L. 2008. A 20 Ma pollen record of East-Asian summer monsoon evolution from Guyuan, Ningxia, China. Palaeogeography, Palaeoclimatology, Palaeoecology, 265: 30-38.

Keatings, K.W., Heaton, T.H.E, Holmes, J.A. 2002.The effects of diagenesis on the trace element and stable isotope geochemistry of non-marine ostracods valves. Journal of Paleolimnology, 28: 245-252

Keatings, K., Holmes, J., Flower, R., Horne, D., Whittaker, J.E. ,Abu-Zied, R.H. 2010. Ostracods and the Holocene palaeolimnology of Lake Qarun, with special reference to past human-environment interactions in the Faiyum (Egypt). 


\section{Hydrobiologia,654:155-176}

Kent-Corson, M. L., Ritts, B. D., Zhuang, G., Bovet, P. M., Graham, S. A., \& Page Chamberlain, C. 2009. Stable isotopic constraints on the tectonic, topographic, and climatic evolution of the northern margin of the Tibetan Plateau. Earth and Planetary Science Letters, 282: 158-166.

Kutzbach, J.E., Guetter, P.J., Ruddiman,W.F., Prell, W.L. 1989. Sensitivity of climate to late Cenozoic uplift in southern Asia and the American west: numerical experiments.Journal of Geophysical Research: Atmospheres, 94:18393-18407.

Lease, R.O., Burbank, D.W., Clark, M.K., Farley, K.A., Zheng, D., Zhang, H. 2011. Middle Miocene reorganization of deformation along the northeastern Tibetan Plateau. Geology,39:359-362.

Leng, M.J., Marshall, J.D. 2004. Palaeoclimate interpretation of stable isotope data from lake sediment archives. Quaternary Science Reviews,23: 811-831

Lister, G.S., Kelts, K., Chen, K.Z., Y, J.Q., Niessen, F. 1991. Lake Qinghai, China: closedBasin lake levels and the oxygen isotope record for ostracoda since the latest Pleistocene. Palaeogeography, Palaeoclimatology, Palaeoecology,84: 141-162.

Liu, T.S. 1985. Loess and the Environment. China Ocean Press, Beijing.pp. 1-251.

Liu, W.G., Li, X.Z., Zhang, L., An, Z.S., Xu, L.M. 2009. Evaluation of oxygen isotopes in carbonate as an indicator of lake evolution in arid areas: the modern Qinghai Lake, Qinghai-Tibet Plateau. Chemical Geology, 268: 126-136.

Li, G..J., Pettke, T., Chen, J. 2011. Increasing Nd isotopic ratio of Asian dust indicates 
progressive uplift of the north Tibetan Plateau since the middle Miocene. Geology, 39:199-202.

Ligios, S., Gliozzi, E. 2012.The genus Cyprideis Jones, 1857 (Crustacea, Ostracoda) in the Neogene of Italy: A geometric morphometric approach. Revue de microp aléontologie,55(4): 171-207.

Li, X.Z., Liu, W.G., Xu, L.M. 2012. Carbon isotopes in surface-sediment carbonates of modern Lake Qinghai (Qinghai-Tibet Plateau): Implications for lake evolution in arid areas. Chemical Geology,300-301: 88-96

Liu, Z.H., Zhang, K.X., Sun, Y.Y., Liu, W.G., Liu, Y.S., Quan, C. 2014.Cenozoic environmental changes in the northern Qaidam Basin inferred from n-alkane records. Acta Geologica Sinica (English Edition),88(5):1547-1555

Lu, H.J., Xiong, S.F. 2009. Magnetostratigraphy of the Dahonggou section, northern Qaidam Basin and its bearing on Cenozoic tectonic evolution of the Qilian Shan and Altyn Tagh Fault. Earth and Planetary Science Letters, 288: 539-550.

Lu, H.Y., Wang, X., Li, L., 2010. Aeolian sediment evidence that global cooling has driven late Cenozoic stepwise aridification in central Asia. Geological Society, London, Special Publications,342: 29-44.

Ma, Y.Z., Fang, X.M., Li, J.J., Wu, F.L., Zhang, J. 2005. The vegetation andclimate change during Neogene and Early Quaternary in Jiuxi Basin, China.Science in China Series D: Earth Sciences,48:676-688.

Marco-Barba, J., Ito, E. Carbonell, E., Mesquita-Joanes, F. 2012. Empirical calibration of shell chemistry of Cyprideis torosa (Jones, 1850) (Crustacea: 
Ostracoda). Geochimica et Cosmochimica Acta,93:143-163

McLennan, S. M., 1993. Weathering and global denudation: Journal of Geology, 101: 295-303.

Metivier, F., Gaudemer, Y., Tapponnier, P., Meyer, B. 1998. Northeastward growth of the Tibet Plateau deduced from balanced reconstruction of two depositional areas: the Qaidam and Hexi Corridor Basins, China. Tectonics,17: 823-842.

Meisch, C. 2000. Freshwater Ostracoda of Western and Central Europe. Spektrum, Heidelberg. pp.1-522.

Mezquita, F., Tapia, G., Roca, J. R. 1999. Ostracoda from springs on the eastern Iberian Peninsula: ecology, biogeography and palaeolimnological implications. Palaeogeography, Palaeoclimatology, Palaeoecology,148: 65-85.

Mezquita, F., Roca, J.R., Reed, J.M., Wansard, G. 2005. Quantifying speciesenvironment relationships in non-marine Ostracoda for ecological and palaeoecological studies: examples using Iberian data. Palaeogeography, Palaeoclimatology, Palaeoecology,225: 93-117.

Miall, A.D. 1996. The Geology of Fluvial Deposits, Sedimentary Facies, Basin Analysis, and Petroleum Geology. Springer, New York. pp.1- 582.

Mischke, S., Wünnemann, B. 2006. The Holocene salinity history of Bosten Lake (Xinjiang, China) inferred from ostracod species assemblages and shell chemistry: possible palaeoclimatic implications. Quaternary International,154-155: 100-112.

Mischke, S., Almogi-Labin, A., Ortal, R., Rosenfeld, A., Schwab, M.J., Boomer, I. 2010. Quantitative reconstruction of lake conductivity in the Quaternary of the 
Near East (Israel) using ostracods. Journal of Paleolimnology,43: 667-688.

Mischke, S., Ginatc, H., Al-Saqaratd, B., Almogi-Labin, A. 2012.Ostracods from water bodies in hyperarid Israel and Jordan as habitat and water chemistry indicators. Ecological Indicators, 14:87-99

Miao, Y.F., Fang, X.M., Herrmann, M., Wu, F.L., Zhang, Y., Liu, D.L. 2011. Miocene pollen record of $\mathrm{KC}-1$ core in the Qaidam Basin, NE Tibetan Plateau and impli cations for evolution of the East Asian monsoon. Palaeogeography, Palaeo climatology, Palaeoecology,209: 30-38.

Miao, Y.F., Herrmann, M., Wu, F.L., Yan, X.L., Yang, S.L. 2012. What controlled Mid-Late Miocene long-term aridification in Central Asia? - Global cooling or Tibetan Plateau uplift: A review. Earth-Science Reviews,112: 155-172

Neale, J.W. 1988. Ostracods and palaeosalinity reconstructions. In: Ostracoda in the Earth Sciences. Edited by P. De Deckker, J.P. Colin. Elsevier, Amsterdam. pp.125-155.

Nesbitt, H.W., Markovics, G., Price, R.C. 1980. Chemical processes affecting alkalis and alkaline earths during continental weathering. Geochimica et Cosmochimica Acta,44: 1659-1666.

Nesbitt, H.W., and Young, G.M. 1982. Early Proterozoic climates and plate motions inferred from major element chemistry of lutites. Nature, 299:715-717.

Nesbitt, H.W., and Young, G.M. 1984. Prediction of some weathering trends of plutonic and volcouldic rocks based on thermodynamic and kinetic considerations. Geochimica et Cosmochimica Acta,48(7): 1523-1534 
Nesbitt, H.W., Young, G.M., McLennan, S.M., and Keays, R.R. 1996. Effects of chemical weathering and sorting on the petrogenesis of siliclastic sediments, with implications for provenance studies. The Journal of Geology,104: 525-542.

O'Neil, J.R., Clayton, R.N., Mayeda, T.K., 1969. Oxygen isotope fractionation in divalent metal carbonates. The University of Chicago.

Ortiz, J.E., Torres, T., Delgado, A., Reyes, E., Llamas, J.F., Soler, V., Raya, J.2006. Pleistocene paleoenvironmental evolution at continental middle latitude inferred from carbon and oxygen stable isotope analysis of ostracodes from the GuadixBaza Basin (Granada, SE Spain). Palaeogeography, Palaeoclimatology, Palaeoecology, 240: 536-561

QBGMR (Qinghai Bureau of Geology and Mineral Resources). 1991. Regional Geology of the Qinghai Province. Geological Publishing House, Beijing. pp.1-662.

Raymo, M.E., Ruddiman,W.F., 1992. Tectonic forcing of late Cenozoic climate. Nature, 359 (6391): 117-122.

Rea, D.K., Snoeckx, H., Joseph, L.H. 1998. Late Cenozoic eolian deposition in the North Pacific: Asian drying, Tibetan uplift, and cooling of the northern hemisphere. Paleoceanography,13: 215-224.

Rozanski, K., Araguás-Araguás, L., Gonfiantini, R. 1993. Isotopic patterns in modern global precipitation. Geophysical Monograph Series,78:1-36.

Royden, L.H., Burchfi el, B.C., and van der Hilst, R.D. 2008. The geological evolution of the Tibetan Plateau: Science, 321: 1054-1058, 
Ruddiman, W.F., Kutzbach, J.E. 1989. Forcing of late Cenozoic northern hemisphere climate by plateau uplift in southern Asia and the American west. Journal of Geophysical Research, 94 (D15): 18409-18427.

Ramstein, G., Fluteau, F., Besse, J., Joussaume, S. 1997. Effect of orogeny, plate motion and land-sea distribution on Eurasian climate over the past 30 million years. Nature, 386:788-795.

Schwalb, A. 2003. Lacustrine ostracodes as stable isotope recorders of late-glacial and Holocene environmental dynamics and climate. Journal of Paleolimnology, 29: 265-351

Song, B.W., Zhang, K.X., Lu, J.F., Wang, C.W., Xu, Y.D. 2013.The middle Eocene to early Miocene integrated sedimentary record in the Qaidam Basin and its implications for paleoclimate and early Tibetan Plateau uplift. Canadian Journal of Earth Sciences, 50: 183-196

Song, C.H, Hu, S.H., Han, W.X., Zhang, T., Fang, X.M., Gao, J.P., Wu, F.L. 2014. Middle Miocene to earliest Pliocene sedimentological and geochemical records of climate change in the western Qaidam Basin on the NE Tibetan Plateau.

Palaeogeography, Palaeoclimatology, Palaeoecology, 395: 67-76.

Stuiver, M. 1970. Oxygen and carbon isotope ratios of fresh-water carbonates as climatic indicators. Journal of Geophysical Research,75: 5247-5257.

Sun, J.M., Zhu, R.X., An, Z.S. 2005.Tectonic uplift in the northern Tibetan Plateau since 13.7 Ma ago inferred from molasse deposits along the Altyn Tagh Fault. Earth and Planetary Science Letters, 235: 641-653. 
Sun, J.M., Ye, J., Wu, W.Y., Ni, X.J., Bi, S.D., Zhang, Z.Q., Liu, W.M., Meng, J. 2010. Late Oligocece-Miocene mid-latitude aridification and wind patterns in the Asian interior. Geology, 38: 515-518.

Sun, J.M., Gong, Z.J., Tian, Z.H., Jia, Y.Y., Windley, B. 2015. Late Miocene stepwise aridification in the Asian interior and the interplay between tectonics and climate. Palaeogeography, Palaeoclimatology, Palaeoecology, 421:48-59.

Sun, Z.M., Yang, Z.Y., Pei, J.L., Ge, X.H., Wang, X.S., Yang, T.S., Li, W.M., Yuan, S. H. 2005. Magnetostratigraphy of Paleogene sediments from northern Qaidam Basin, China: Implications for tectonic uplift and block rotation in northern Tibetan plateau. Earth and Planetary Science Letters, 237(3-4): 635-646

Sun, Z.C., Feng, X.J., Li, D.M., Yang, F. ,Qu, Y.H., Wang, H.J.1999.Cenozoic Ostracoda and palaeoenvironments of the northeastern Tarim Basin, western China. Palaeogeography, Palaeoclimatology, Palaeoecology, 148(1):37-50.

Sylvester-Bradley, P.C.1961. Archaeocopida. Treatise on Invertebrate Paleontology Part Q, Arthropoda, 3: Q100-Q103.

Talbot, M.R.1990. A review of palaeohydrological interpretations of carbon and hydrogen isotopic ratios in primary lacustrine carbonates. Chemical Geology, 80: 261-279.

Tang, Z.H., Ding, Z.L., White, P.D., Dong, X.X., Ji, J.L., Jiang, H.C., Luo, P., Wang, X. 2011. Late Cenozoic central Asian drying inferred from a palynological record from the northern Tian Shan. Earth and Planetary Science Letters, 302: 439-447. 
Tang, Z.H., Ding, Z.L. 2013.A palynological insight into the Miocene aridification in the Eurasian interior. Palaeoworld, 22: 77-85.

Turpen, J.B. and Angell, R.W. 1971. Aspects of molting and calcification in the ostracode Heterocypris. Biological Bulletin of the Marine Biology Laboratory, 140:331-338.

Van den Bold, W.A. 1976. Distribution of species of tribe Cyprideidini (Ostracoda, Cytherideidae) in the Neogene of the Caribbean. Micropaleontology, 22 (1): 1-43.

Van Baak, C. G. C., Vasiliev, I., Stoica, M., Kuiper, K. F., Forte, A. M., Aliyeva, E., Krijgsman, W. 2012. A magnetostratigraphic time frame for Plio-Pleistocene transgressions in the South Caspian Basin, Azerbaijan.Global and planetary change, 103: 119-134.

Viehberg, F.A, Frenzel, P., Hoffmann, G. 2008.Succession of late Pleistocene and Holocene ostracode assemblages in a transgressive environment: A study at a coastal locality of the southern Baltic Sea (Germany). Palaeogeography, Palaeoclimatology, Palaeoecology, 264: 318-329

von Grafenstein, U., Erlenkeuser, H., Müller, J. , Kleinmann-Eisenmann, A. 1992.

Oxygen isotope records of benthic ostracods in Bavarian lake sediments, reconstruction of late and post glacial air temperatures. Naturwissenschaften,79: 145-152.

von Grafenstein, U., Erlenkeuser, H., Trimborn, P. 1999. Oxygen and carbon isotopes in modern fresh-water ostracods valves: assessing vital offsets and autecological effects of interest for paleoclimate studies. Palaeogeography, Palaeoclimatology, 
Palaeoecology, 148: 133-152.

Wang, C.W., Hong, H.L., Li.,C.H., Liang, G.J., Xie, J., Song, B.W., Song, E.P., Zhang, K.X. 2013. Climatic and tectonic evolution in the north Qaidam since the Cenozoic: Evidence from sedimentology and mineralogy. Journal of Earth Science, 24: $314-327$.

Wang, X, Sun, D.H., Chen, F.H., Wang, F., Li, B.F., Popov, S.V., Wu, S, Zhang, Y.B., Li, Z.J. 2014.Cenozoic paleo-environmental evolution of the Pamir-Tien Shan convergence zone. Journal of Asian Earth Sciences, 80: 84-100.

Wang, Y., Deng, T., 2005. A 25 m.y. isotopic record of paleodiet and environmental change from fossil mammals and paleosols from the NE margin of the Tibetan Plateau. Earth and Planetary Science Letters, 236: 322-338.

Wang, Y., Deng, T., Flynn, L., Wang, X.F., Yin, A., Xu, Y.F., Parker, W., Lochner, E., Zhang, C.F., Biasatti, D. 2012. Late Neogene environmental changes in the central Himalaya related to tectonic uplift and orbital forcing. Journal of Asian Earth Sciences, 44: 62-76.

Wintsch, R.P., Kvale, C.M. 1994. Differential mobility of elements in burial diagenesis of siliciclastic rocks. Journal of Sedimentary Research, A64: 349-361. Xiao, G.Q., Guo, Z.T., Dupont-Nivet, G., Lu, H.Y., Wu, N.Q., Ge, J.Y., Hao, Q.Z., Peng, S.Z., Li, F.J., Abels, H.A., Zhang, K.X., 2012. Evidence for northeastern Tibetan Plateau uplift between 25 and $20 \mathrm{Ma}$ in the sedimentary archive of the Xining Basin, Northwestern China. Earth and Planetary Science Letters, 317-318: 185-195. 
Yang, F., Qiao Z.Z., Zhang, H.Q., Zhang, Y.H., Sun, Z.C. 2006. Features of the Cenozoic ostrocod fauna and environmental significance in Qaidam Basin. Journal of Palaeogeography, 8: 143-156

Yang, P. 2000. Ostracodsa extinction and explosion events of the Mesozoic-cenozoic in Qaidam baisn,North China. Journal of palaeogeography, 2(3): 69-74

Yin, A., Dang, Y., Zhang, M., Chen, X., and McRivette, M. W. 2008. Cenozoic tectonic evolution of the Qaidam Basin and its surrounding regions (Part 3): Structural geology, sedimentation, and regional tectonic reconstruction. Geological Society of America Bulletin,120: 847-876

Young, G.M., Nesbitt, H.W. 1998. Processes controlling the distribution of Ti and Al in weathering profiles, siliciclastic sediments and sedimentary rocks. Journal of Sedimentary research, 68: 448-455.

Yu, X.H. 1994. Cenozoic potassic alkaline ultrabasic volcanic rocks and its genesis in Lixian-Dangchang area, Gansu Province. Tethyan Geology,18:114-129.

Zachos, J., Pagani, M., Sloan, L., Thomas, E., Billups, K. 2001. Trends, rhythms, and aberrations in global climate 65 Ma to present. Science, 292: 686-693.

Zachos, J.C., Dickens,G.R. and Zeebe, R.E. 2008. An Early Cenozoic perspective on greenhouse warming and carbon-cycle dynamics. Nature, 451:279-283.

Zhang, C.X., Xiao, G.Q., Guo, Z.T., Wu, H.B., Hao, Q.Z.2015.Evidence of late early Miocene aridification intensification in the Xining Basin caused by the northeastern Tibetan Plateau uplift. Global and Planetary Change, 128: 31-46.

Zhang, Z.G., Han, W.X., Fang, X.M.,Song, C.H., Li,X.Y.2013. Late 
Miocene-Pleistocene aridification of Asian inland revealed by geochemical records of lacustrine-fan delta sediments from the western Tarim Basin, NW China. Palaeogeography, Palaeoclimatology, Palaeoecology, 377: 52-61.

Zhuang, G.S., Hourigan, J.K., Koch, P.L., Ritts, B.D., Kent-Corson, M.L. 2011 a. Isotopic constraints on intensified aridity in Central Asia around 12 Ma. Earth and Planetary Science Letters, 312: 152-163.

Zhuang, G.S., Hourigan, J.K., Ritts, B.D., Kent-Corson, M.L. 2011b.Cenozoic multiple- phase tectonic evolution of the northern Tibetan Plateau: Constraints from sedimentary records from Qaidam Basin, Hexi Corridor, and Subei Basin, northwest China. American Journal of Science, 311:116-152.

Zhuang, G.S., Brandon,M.T., Pagani, M., Krishnan,S.. 2014. Leaf wax stable isotopes from Northern Tibetan Plateau: Implications for uplift and climate since $15 \mathrm{Ma}$. Earth and Planetary Science Letters, 390: 186-198.

Fig 1. (a). The simplified geology map showing Cenozoic major faults in the Tibetan Plateau. (b). The topography map showing the study area. (c). Geological map of the Dahonggou anticline and location of our studied section.

Fig 2. Chronology and stratigraphy of the sedimentary sequence: a. Magnetostratigraphy of the sequence based on Lu and Xiong(2009) and the geomagnetic polarity timescale (GPTS) based on Gradstein et al.(2004). b. Lithology of the sedimentary sequence. c. Google Earth image (www.earth.google.com) of the section showing the correlation between our measured section and section-q and section-k (Lu and Xiong 2009). 
Fig 3. Stratigraphic correlation between the sequence of this study and Section-k and Section-q reported by Lu and Xiong(2009): a. the marker layer consisting of thick green mudstone designated bed 386 . b. the marker layer characterized by characteristic folds, designated bed 334 .

Fig 4. Distribution of ostracods in the lower part of the SYSS Formation of the DHG section, Qaidam Basin.

Fig 5. Scanning electron micrographs of typical ostracod valves. 1, 2: Ilyocypris. cf. gibba, 1: left valve (LV) external view (ev), 2: right valve (RV) ev; 3, 4: $I$. bradyi, 3: RV ev, 4: LV ev; 5: Cyprinotus gibbus, RV ev; 6: Leucocythere mirabilis, LV ev; 7: L. dorsotuberosa, LV ev; 8: Candoniella albicans, LV ev; 9: Candoniella suzini, RV ev; 10: Candoniella foliaceus, RV ev; 11: Potamocypris longisetosa, LV ev; 12. Leucocytherella hyalina, LV ev; 13: Cyprinotus salinus, RV ev; 14: Cypris acuta, LV ev; 15: Cyclocypris glacialis, LV ev; 16: Cyprideis Subtera, RV ev; 17: Cyprideis sp., RV ev; 18: Cyprideis cf. subeboliangensis, RV ev; 19-21: Cyprideis torosa, 19: RV ev; 20: RV; 21: RV ev (juvenile). All specimens are housed at the State Key Laboratory of Biogeology and Environmental Geology, China University of Geoscience s, Wuhan.

Fig 6. Scatter plot of stable isotopic compositions $\left(\delta^{13} \mathrm{C}\right.$ and $\delta^{18} \mathrm{O}$; VPDB notation) of calcitic ostracod valves. The $\delta^{18} \mathrm{O}$ values of ostracods have been normalized by subtracting the species-specific offset values reported by various authors.

Fig 7. a. Stable isotope records $\left(\delta^{18} \mathrm{O}\right.$ and $\left.\delta^{13} \mathrm{C}\right)$ of ostracod calcite from the sequence 
in the DHG section. b. vertical distribution of the CIW and $\mathrm{K} / \mathrm{Na}$ ratios from the sequence in the DHG section. c. vertical distribution of Ti/Al ratios from the sequence in the DHG section. d. vertical distribution of evaporite minerals from the sequence in the DHG section (Wang et al. 2013).

Fig 8. Map showing evidence of extensive aridification of inland Asia at approximately $13 \mathrm{Ma}$.

Table 1. Major element concentrations (wt.\%) and CIW and K/Na values from the sequence in the DHG section.

Table 2. $\mathrm{O}$ and $\mathrm{C}$ isotope values of selected ostracod species from the sequence in the DHG section. The $\delta^{18} \mathrm{O}$ values of the three analyzed species were normalized by subtracting the vital-offset values relative to theoretical inorganic calcite in equilibrium(Marco-Barba et al. 2012; Decrouy et al. 2011; Belis and Ariztegui 2004; Anadón et al. 2012) 
Table 1. Major (wt.\%) element concentrations and CIW, K/Na from studied sedimentary sequence of Dahonggou section.

\begin{tabular}{|c|c|c|c|c|c|c|c|c|c|c|c|c|c|c|c|c|c|c|}
\hline Sample & Lithology & $\begin{array}{c}\text { Depth } \\
\text { (m) }\end{array}$ & $\mathrm{Na}_{2} \mathrm{O}$ & MgO & $\mathbf{A l}_{2} \mathbf{O}_{3}$ & $\mathrm{SiO}_{2}$ & $\mathbf{P}_{2} \mathbf{O}_{5}$ & $\mathbf{K}_{2} \mathbf{O}$ & $\mathrm{CaO}$ & $\mathrm{TiO}_{2}$ & MnO & $\mathrm{Fe}_{2} \mathrm{O}_{3}$ & $\mathrm{FeO}$ & $\mathrm{H}_{2} \mathrm{O}^{+}$ & $\mathrm{CO}_{2}$ & CIW & $\mathbf{K} / \mathbf{N a}$ & Ti/Al \\
\hline S27-HM-334-1 & mudstone & 3316.6 & 2.41 & 1.59 & 10.92 & 68.33 & 0.14 & 2.24 & 5.16 & 0.57 & 0.06 & 1.66 & 1.42 & 1.80 & 3.45 & 57.93 & 0.61 & 0.06 \\
\hline S27-HM-335-1 & mudstone & 3323.6 & 2.32 & 2.37 & 13.16 & 62.51 & 0.14 & 2.76 & 4.39 & 0.69 & 0.06 & 3.60 & 1.45 & 2.69 & 3.56 & 55.83 & 0.78 & 0.06 \\
\hline S27-HM-336-1 & mudstone & 3344.1 & 2.04 & 3.19 & 15.94 & 51.24 & 0.16 & 3.45 & 6.41 & 0.69 & 0.09 & 5.37 & 1.70 & 4.22 & 5.02 & 67.62 & 0.98 & 0.05 \\
\hline S27-HM-337-1 & mudstone & 3425.1 & 2.25 & 3.50 & 14.17 & 42.98 & 0.15 & 2.92 & 11.45 & 0.64 & 0.23 & 4.85 & 1.73 & 3.80 & 7.95 & 65.68 & 0.85 & 0.05 \\
\hline S27-HM-338-1 & mudstone & 3458.6 & 2.35 & 1.60 & 12.08 & 70.85 & 0.11 & 2.40 & 2.65 & 0.60 & 0.04 & 1.47 & 1.45 & 2.34 & 1.83 & 60.97 & 0.67 & 0.06 \\
\hline S27-HM-339-1 & mudstone & 3505.6 & 2.26 & 1.38 & 10.90 & 71.79 & 0.13 & 2.18 & 3.57 & 0.60 & 0.04 & 1.29 & 1.33 & 1.88 & 1.36 & 63.55 & 1.07 & 0.05 \\
\hline S27-HM-339-2 & mudstone & 3507.2 & 1.90 & 2.54 & 15.05 & 55.46 & 0.16 & 3.10 & 5.94 & 0.73 & 0.10 & 4.52 & 1.85 & 3.75 & 4.81 & 82.80 & 1.07 & 0.06 \\
\hline S27-HM-340-1 & mudstone & 3510 & 1.76 & 2.38 & 15.44 & 61.61 & 0.12 & 3.32 & 2.57 & 0.67 & 0.06 & 4.93 & 1.65 & 3.57 & 1.73 & 84.21 & 1.24 & 0.05 \\
\hline S27-HM-341-1 & mudstone & 3516.9 & 2.19 & 0.59 & 8.41 & 79.47 & 0.05 & 2.03 & 3.02 & 0.27 & 0.03 & 0.67 & 0.55 & 0.95 & 1.57 & 53.86 & 0.61 & 0.04 \\
\hline S27-HM-342-1 & mudstone & 3519.8 & 1.54 & 3.24 & 15.90 & 46.23 & 0.14 & 3.51 & 9.22 & 0.67 & 0.15 & 5.72 & 1.68 & 3.99 & 7.74 & 86.26 & 1.50 & 0.04 \\
\hline S27-HM-344-1 & mudstone & 3527 & 1.60 & 2.69 & 16.66 & 56.44 & 0.19 & 3.58 & 4.03 & 0.68 & 0.08 & 4.66 & 2.08 & 4.24 & 2.93 & 86.36 & 1.47 & 0.04 \\
\hline S27-HM-345-1 & mudstone & 3531 & 2.14 & 2.19 & 15.25 & 61.02 & 0.13 & 3.06 & 3.32 & 0.76 & 0.06 & 3.81 & 1.88 & 3.41 & 2.72 & 81.24 & 0.94 & 0.05 \\
\hline S27-HM-346-1 & mudstone & 3532.5 & 2.07 & 2.38 & 12.90 & 59.89 & 0.14 & 2.68 & 6.60 & 0.66 & 0.08 & 2.84 & 1.68 & 2.87 & 4.92 & 79.12 & 0.85 & 0.05 \\
\hline S27-HM-347-1 & mudstone & 3537.2 & 1.68 & 3.32 & 15.45 & 48.98 & 0.12 & 3.41 & 8.25 & 0.70 & 0.08 & 5.32 & 1.60 & 3.96 & 6.80 & 84.83 & 1.34 & 0.05 \\
\hline S27-HM-348-1 & mudstone & 3542.5 & 1.89 & 2.44 & 15.66 & 58.57 & 0.14 & 3.18 & 4.02 & 0.78 & 0.08 & 4.45 & 1.83 & 3.85 & 2.93 & 83.43 & 1.11 & 0.05 \\
\hline S27-HM-349-1 & mudstone & 3547.3 & 2.14 & 1.87 & 11.55 & 65.01 & 0.13 & 2.45 & 5.68 & 0.57 & 0.06 & 2.77 & 1.20 & 2.38 & 4.18 & 62.13 & 0.75 & 0.06 \\
\hline S27-HM-350-1 & mudstone & 3550.6 & 1.63 & 3.42 & 14.46 & 53.10 & 0.15 & 3.09 & 7.15 & 0.71 & 0.09 & 4.33 & 2.07 & 3.80 & 5.75 & 84.36 & 1.25 & 0.05 \\
\hline S27-HM-351-1 & mudstone & 3557 & 1.43 & 3.50 & 16.90 & 49.77 & 0.12 & 3.76 & 6.68 & 0.70 & 0.08 & 4.93 & 2.00 & 4.16 & 5.65 & 87.78 & 1.73 & 0.04 \\
\hline S27-HM-352-1 & mudstone & 3562.3 & 2.24 & 2.58 & 13.73 & 57.74 & 0.14 & 2.84 & 5.74 & 0.66 & 0.08 & 4.20 & 1.57 & 3.55 & 4.60 & 78.84 & 0.83 & 0.05 \\
\hline S27-HM-353-1 & mudstone & 3569.4 & 2.09 & 2.69 & 12.57 & 53.07 & 0.14 & 2.61 & 9.52 & 0.67 & 0.11 & 3.60 & 1.43 & 3.20 & 7.32 & 78.52 & 0.82 & 0.05 \\
\hline S27-HM-354-1 & mudstone & 3576.4 & 4.21 & 3.16 & 12.33 & 41.83 & 0.11 & 2.04 & 10.34 & 0.57 & 0.11 & 4.52 & 1.18 & 4.79 & 8.16 & 64.03 & 0.32 & 0.05 \\
\hline
\end{tabular}




\begin{tabular}{|c|c|c|c|c|c|c|c|c|c|c|c|c|c|c|c|c|c|c|}
\hline S27-HM-355-1 & mudstone & 3587.3 & 2.98 & 2.61 & 11.97 & 49.47 & 0.20 & 2.11 & 10.51 & 0.59 & 0.18 & 3.33 & 1.43 & 2.95 & 7.95 & 70.94 & 0.47 & 0.05 \\
\hline S27-HM-356-1 & mudstone & 3595.2 & 2.99 & 1.93 & 10.41 & 52.46 & 0.12 & 1.69 & 11.85 & 0.57 & 0.11 & 2.72 & 0.88 & 2.74 & 9.21 & 67.91 & 0.37 & 0.05 \\
\hline S27-HM-357-1 & mudstone & 3597.5 & 4.51 & 2.19 & 11.07 & 58.32 & 0.10 & 2.02 & 5.08 & 0.47 & 0.07 & 3.36 & 0.72 & 2.78 & 3.56 & 4.51 & 2.19 & 0.05 \\
\hline S27-HM-358-1 & mudstone & 3599.6 & 3.23 & 1.88 & 10.98 & 63.61 & 0.10 & 2.16 & 4.99 & 0.51 & 0.06 & 3.14 & 0.58 & 2.81 & 3.24 & 67.39 & 0.44 & 0.05 \\
\hline S27-HM-360-1 & mudstone & 3607.3 & 3.39 & 1.60 & 10.37 & 66.46 & 0.11 & 2.00 & 4.78 & 0.55 & 0.06 & 2.80 & 0.53 & 2.35 & 3.87 & 65.03 & 0.39 & 0.05 \\
\hline S27-HM-361-1 & mudstone & 3610.8 & 2.21 & 2.40 & 12.77 & 60.77 & 0.10 & 2.76 & 5.61 & 0.52 & 0.08 & 3.79 & 1.20 & 3.00 & 4.50 & 77.84 & 0.82 & 0.04 \\
\hline S27-HM-364-1 & mudstone & 3633.6 & 2.02 & 2.85 & 13.58 & 56.64 & 0.15 & 2.93 & 6.80 & 0.66 & 0.10 & 3.88 & 1.55 & 3.33 & 5.21 & 80.34 & 0.95 & 0.05 \\
\hline S27-HM-365-1 & mudstone & 3637.4 & 1.89 & 1.29 & 8.29 & 51.44 & 0.11 & 1.74 & 16.87 & 0.43 & 0.18 & 1.56 & 0.85 & 1.84 & 13.38 & 72.72 & 0.61 & 0.05 \\
\hline S27-HM-366-1 & mudstone & 3646.2 & 2.19 & 3.44 & 16.20 & 52.07 & 0.11 & 3.55 & 5.30 & 0.67 & 0.07 & 5.57 & 1.63 & 4.34 & 3.89 & 81.81 & 1.07 & 0.04 \\
\hline S27-HM-367-1 & mudstone & 3659.4 & 2.33 & 2.84 & 13.82 & 50.70 & & 2.91 & & 0.66 & & 4.48 & 1.28 & 3.52 & 6.95 & 78.29 & 0.82 & 0.05 \\
\hline S27-HM-368-1 & mudstone & 3665.8 & 2.36 & 1.88 & 13.05 & 63.59 & 0.14 & 2.64 & 4.59 & 0.69 & 0.05 & 3.30 & 1.27 & 2.92 & 3.45 & 77.07 & 0.74 & 0.05 \\
\hline S27-HM-373-1 & mudstone & 3704 & 2.14 & 2.88 & 14.49 & 55.12 & 0.13 & 3.09 & 6.33 & 0.65 & 0.08 & 4.81 & 1.27 & 3.86 & 4.91 & 80.45 & 0.95 & 0.04 \\
\hline S27-HM-376-1 & mudstone & 3718.5 & 3.23 & 1.95 & 11.07 & 61.77 & 0.10 & 2.22 & 5.62 & 0.46 & 0.06 & 2.80 & 0.88 & 2.76 & 3.66 & 67.57 & 0.45 & 0.04 \\
\hline S27-HM-377-1 & mudstone & 3740 & 3.74 & 2.55 & 12.96 & 57.18 & 0.09 & 2.83 & 5.25 & 0.50 & 0.06 & 4.03 & 1.00 & 3.41 & 3.87 & 67.81 & 0.50 & 0.04 \\
\hline S27-HM-378-1 & mudstone & 3743.8 & 3.20 & 3.32 & 13.87 & 53.40 & 0.14 & 2.98 & 6.05 & 0.64 & 0.09 & 3.94 & 1.20 & 4.09 & 4.18 & 72.49 & 0.61 & 0.05 \\
\hline S27-HM-379-1 & mudstone & 3760 & 3.58 & 2.70 & 13.48 & 55.08 & 0.14 & 2.74 & 6.08 & 0.67 & 0.08 & 4.13 & 1.18 & 3.41 & 4.29 & 69.59 & 0.50 & 0.05 \\
\hline S27-HM-380-1 & mudstone & 3770 & 3.28 & 1.83 & 11.00 & 64.17 & 0.13 & 2.23 & 5.34 & 0.59 & 0.06 & 2.81 & 0.93 & 2.39 & 2.82 & 67.09 & 0.45 & 0.05 \\
\hline S27-HM-381-1 & mudstone & 3778.5 & 1.83 & 2.51 & 13.19 & 58.69 & 0.14 & 2.82 & 6.79 & 0.66 & 0.08 & 3.63 & 1.33 & 3.26 & 4.92 & 81.42 & 1.01 & 0.05 \\
\hline
\end{tabular}




\begin{tabular}{|c|c|c|c|c|c|c|c|c|c|c|c|c|c|c|c|c|c|c|}
\hline S27-HM-382-1 & mudstone & 3787.4 & 2.12 & 2.91 & 14.01 & 56.19 & 0.15 & 3.01 & 6.53 & 0.66 & 0.09 & 4.21 & 1.40 & 3.58 & 5.02 & 80.07 & 0.93 & 0.05 \\
\hline S27-HM-383-1 & mudstone & 3795 & 2.07 & 2.04 & 11.93 & 63.30 & 0.12 & 2.64 & 5.98 & 0.59 & 0.06 & 3.14 & 1.18 & 2.59 & 4.29 & 77.79 & 0.84 & 0.05 \\
\hline S27-HM-384-1 & mudstone & 3797.8 & 2.41 & 2.23 & 13.12 & 63.02 & 0.13 & 2.85 & 4.34 & 0.68 & 0.06 & 3.59 & 1.42 & 2.83 & 3.14 & 76.79 & 0.78 & 0.05 \\
\hline S27-HM-385-1 & mudstone & 3806 & 2.29 & 2.29 & 11.08 & 53.14 & 0.12 & 2.29 & 11.48 & 0.56 & 0.14 & 2.96 & 1.23 & 2.58 & 9.09 & 74.63 & 0.66 & 0.05 \\
\hline
\end{tabular}


Table 2. Oxygen and carbon isotope values of selected ostracod species from the studied sedimentary sequence in the DHG section. The $\delta^{18} \mathrm{O}$ values of the three analyzed species were normalized by subtracting the vital-offset values relative to the theoretical inorganic calcite in equilibrium (Marco-Barba et al., 2012; Decrouy et al., 2011; Belis and Ariztegui, 2004; Anadón et al., 2012)

\begin{tabular}{|c|c|c|c|c|c|}
\hline Sample & Depth (m) & Ostracod species & $\begin{array}{c}\delta^{13} \mathbf{C}(\%) \\
(\mathrm{VPDB})\end{array}$ & $\begin{array}{c}\delta^{18} \mathbf{O}(\%) \\
(\mathrm{VPDB})\end{array}$ & $\begin{array}{c}\delta^{18} \mathbf{O}(\%) \text { normalized } \\
\text { (VPDB) }\end{array}$ \\
\hline S27-335-7 & 3324.0 & Ilyocypris bradyi & -7.00 & -8.23 & -12.13 \\
\hline S27-336-21 & 3338.2 & Candoniella albicans & -6.41 & -6.90 & -9.90 \\
\hline S27-336-25 & 3341.5 & Cyprideis torosa & -5.12 & -11.22 & -13.22 \\
\hline S27-336-29 & 3346.5 & Cyprideis torosa & -4.44 & -8.94 & -10.94 \\
\hline S27-336-42 & 3374.5 & Cyprideis torosa & -6.19 & -12.28 & -14.28 \\
\hline S27-337-5 & 3429.2 & Ilyocypris bradyi & -9.87 & -7.51 & -11.41 \\
\hline S27-338-2 & 3436.5 & Ilyocypris bradyi & -8.12 & -8.69 & -12.59 \\
\hline S27-338-3 & 3441.0 & Ilyocypris bradyi & -8.23 & -11.23 & -15.13 \\
\hline S27-338-7 & 3459.6 & Candoniella albicans & -6.89 & -12.59 & -15.59 \\
\hline S27-338-9 & 3470.4 & Candoniella albicans & -7.14 & -7.11 & -10.11 \\
\hline S27-338-15 & 3494 & Ilyocypris bradyi & -7.07 & -7.92 & -11.82 \\
\hline S27-342-2 & 3518.8 & Ilyocypris bradyi & -6.90 & -8.07 & -11.97 \\
\hline S27-345-1 & 3531.3 & Ilyocypris bradyi & -4.04 & -9.38 & -13.28 \\
\hline S27-347-3 & 3538.5 & Cyprideis torosa & -4.11 & -8.06 & -10.06 \\
\hline S27-348-1 & 3542.5 & Candoniella albicans & -7.36 & -8.14 & -11.14 \\
\hline S27-349-1 & 3548.5 & Cyprideis torosa & -7.66 & -9.30 & -13.20 \\
\hline S27-350-1 & 3555.3 & Cyprideis torosa & -4.40 & -7.16 & -11.05 \\
\hline S27-355-1 & 3585.3 & Cyprideis torosa & -1.22 & -6.22 & -8.22 \\
\hline S27-359-3 & 3602.5 & Cyprideis torosa & -3.32 & -5.89 & -7.89 \\
\hline S27-362-1 & 3614.5 & Cyprideis torosa & -1.92 & -6.38 & -8.38 \\
\hline S27-363-5 & 3620.2 & Cyprideis torosa & -1.60 & -6.26 & -8.26 \\
\hline S27-365-1 & 3638.4 & Cyprideis torosa & -0.62 & -6.24 & -8.24 \\
\hline S27-385-1 & 3803.8 & Cyprideis torosa & -0.56 & -6.81 & -8.81 \\
\hline S27-385-3 & 3804.2 & Cyprideis torosa & -0.490 & -6.74 & -8.74 \\
\hline S27-385-6 & 3805.8 & Cyprideis torosa & -0.28 & -7.21 & -9.21 \\
\hline
\end{tabular}



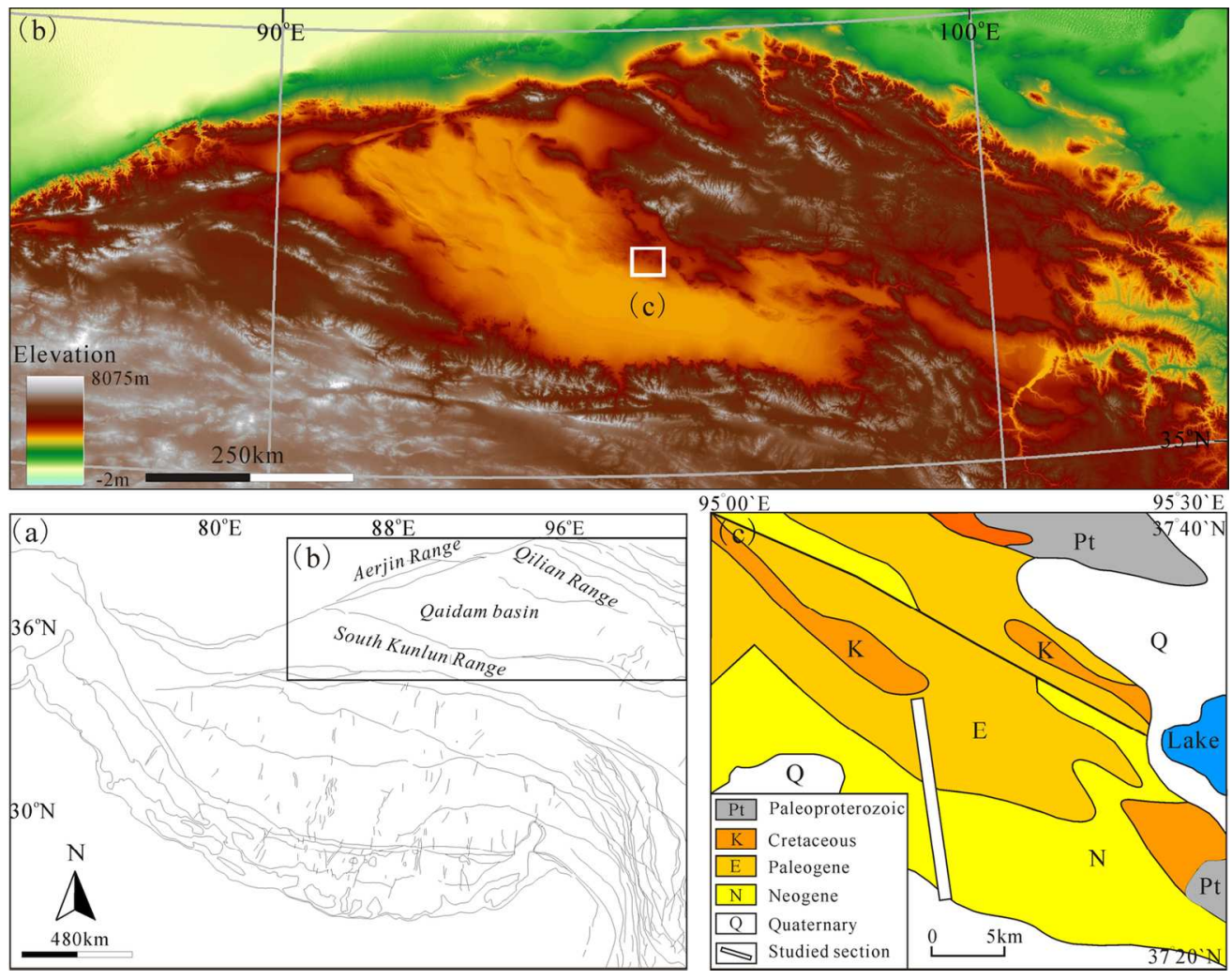

Fig 1. (a). The simplified geology map showing Cenozoic major faults in the Tibetan Plateau. (b). The topography map showing the study area. (c). Geological map of the Dahonggou anticline and location of our studied section.

$138 \times 109 \mathrm{~mm}(300 \times 300$ DPI $)$ 


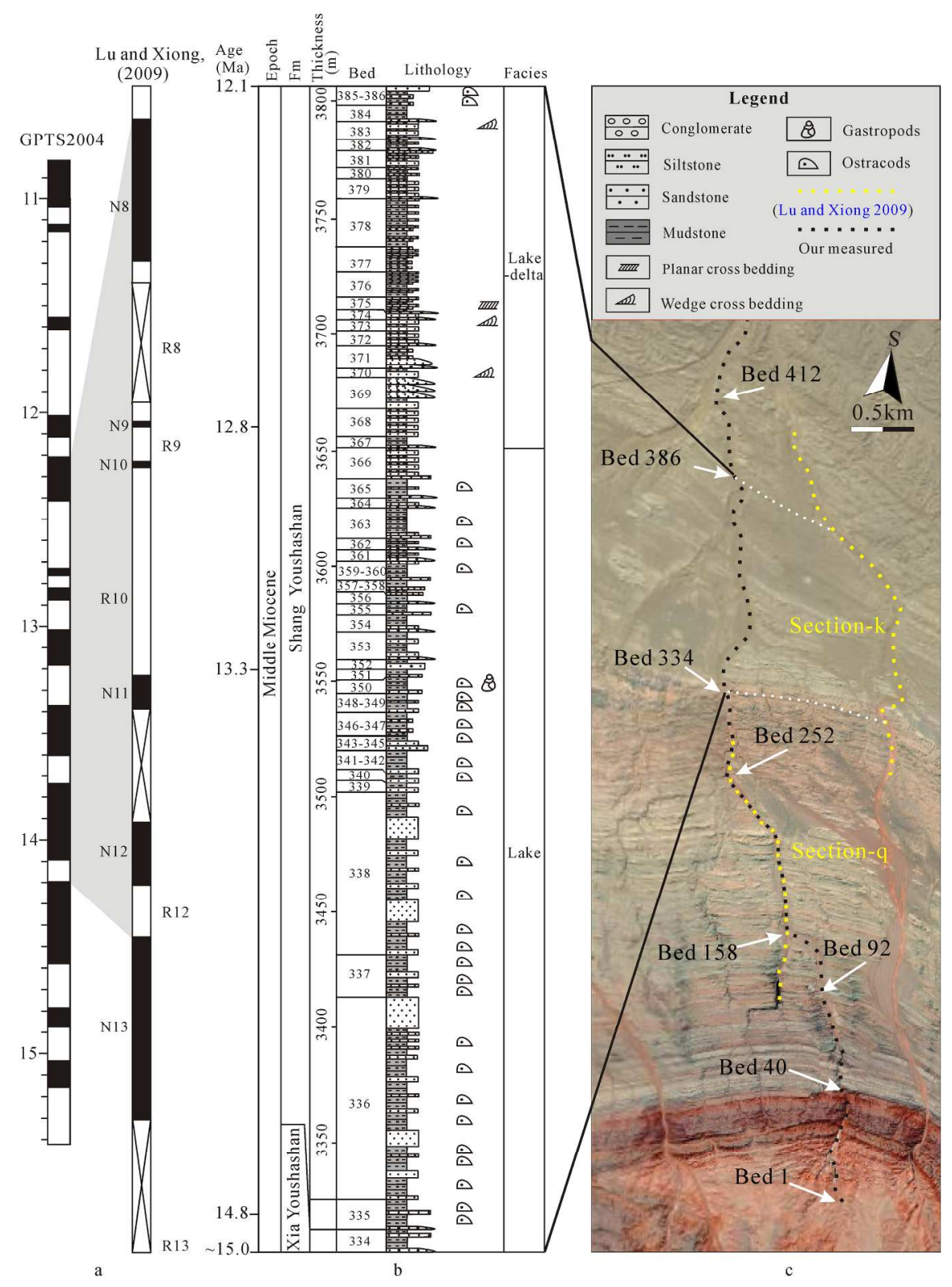

Fig 2. Chronology and stratigraphy of the sedimentary sequence: a. Magnetostratigraphy of the sequence based on Lu and Xiong(2009) and the geomagnetic polarity timescale (GPTS) based on Gradstein et al.(2004). b. Lithology of the sedimentary sequence. c. Google Earth image (www.earth.google.com) of the section showing the correlation between our measured section and section- $\mathrm{q}$ and section-k (Lu and Xiong 2009).

$201 \times 275 \mathrm{~mm}(300 \times 300$ DPI) 


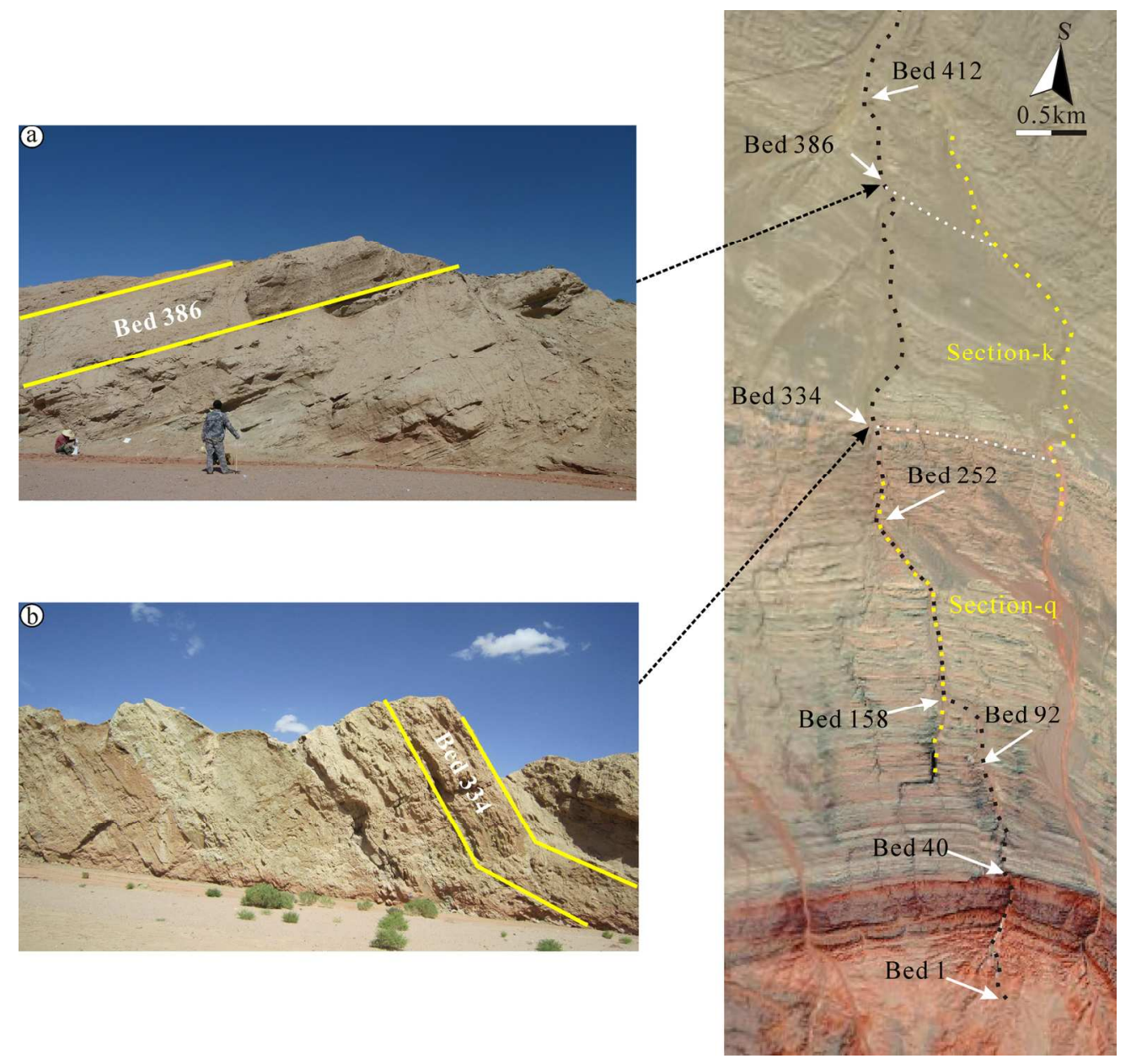

Fig 3. Stratigraphic correlation between the sequence of this study and Section-k and Section-q reported by Lu and Xiong(2009): a. the marker layer consisting of thick green mudstone designated bed 386. $\mathrm{b}$. the marker layer characterized by characteristic folds, designated bed 334.

$148 \times 141 \mathrm{~mm}$ ( $300 \times 300$ DPI) 


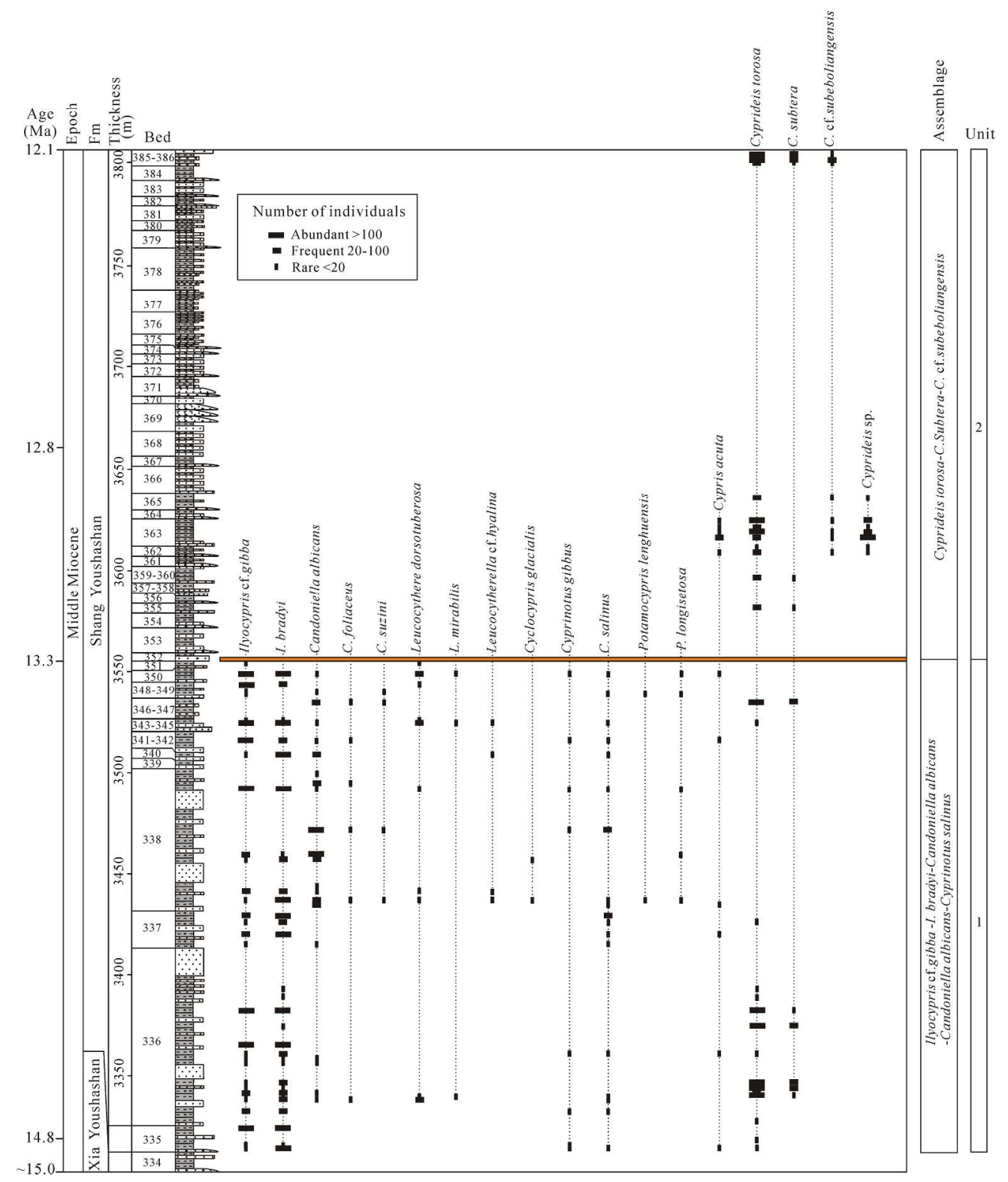

Fig 4. Distribution of ostracods in the lower part of the SYSS Formation of the DHG section, Qaidam Basin. $239 \times 284 \mathrm{~mm}(300 \times 300$ DPI $)$ 


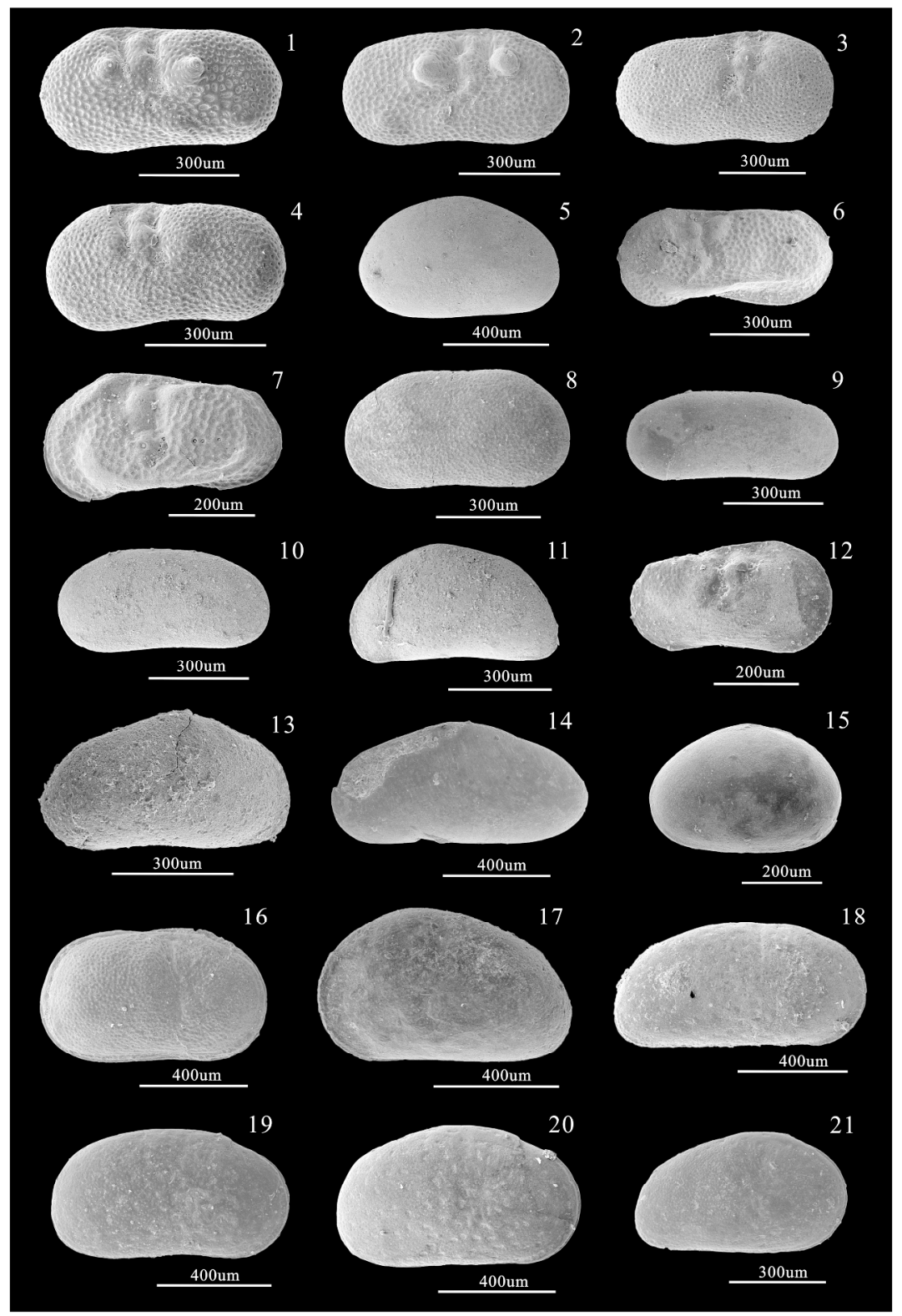

Fig 5. Scanning electron micrographs of typical ostracod valves. 1, 2: Ilyocypris. cf. gibba, 1: left valve (LV) external view (ev), 2: right valve (RV) ev; 3, 4: I. bradyi, 3: RV ev, 4: LV ev; 5: Cyprinotus gibbus, RV ev; 6: Leucocythere mirabilis, LV ev; 7: L. dorsotuberosa, LV ev; 8: Candoniella albicans, LV ev; 9: Candoniella suzini, RV ev; 10: Candoniella foliaceus, RV ev; 11: Potamocypris longisetosa, LV ev; 12 . Leucocytherella hyalina, LV ev; 13: Cyprinotus salinus, RV ev; 14: Cypris acuta, LV ev; 15: Cyclocypris glacialis, LV ev; 16:

Cyprideis Subtera, RV ev; 17: Cyprideis sp., RV ev; 18: Cyprideis cf. subeboliangensis, RV ev; 19-21:

Cyprideis torosa, 19: RV ev; 20: RV; 21: RV ev (juvenile). All specimens are housed the State Key Laboratory of Biogeology and Environmental Geology, China University of Geoscience s, Wuhan.

$$
223 \times 330 \mathrm{~mm}(300 \times 300 \text { DPI) }
$$




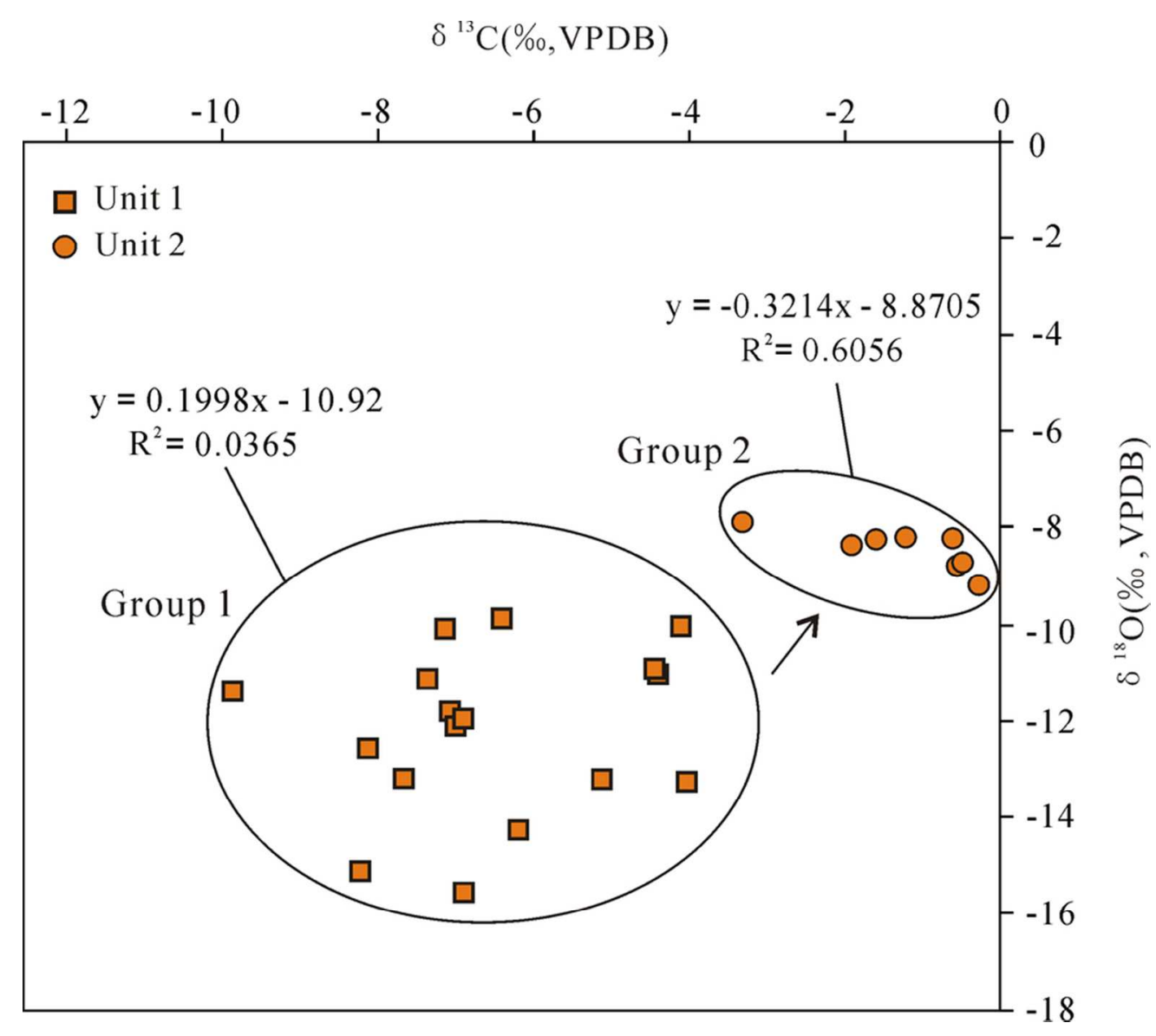

Fig 6. Scatter plot of stable isotopic compositions ( $\delta 13 \mathrm{C}$ and $\delta 180$; VPDB notation) of calcitic ostracod valves. The $\delta 180$ values of ostracods have been normalized by subtracting the species-specific offset values reported by various authors.

$82 \times 73 \mathrm{~mm}(300 \times 300$ DPI) 


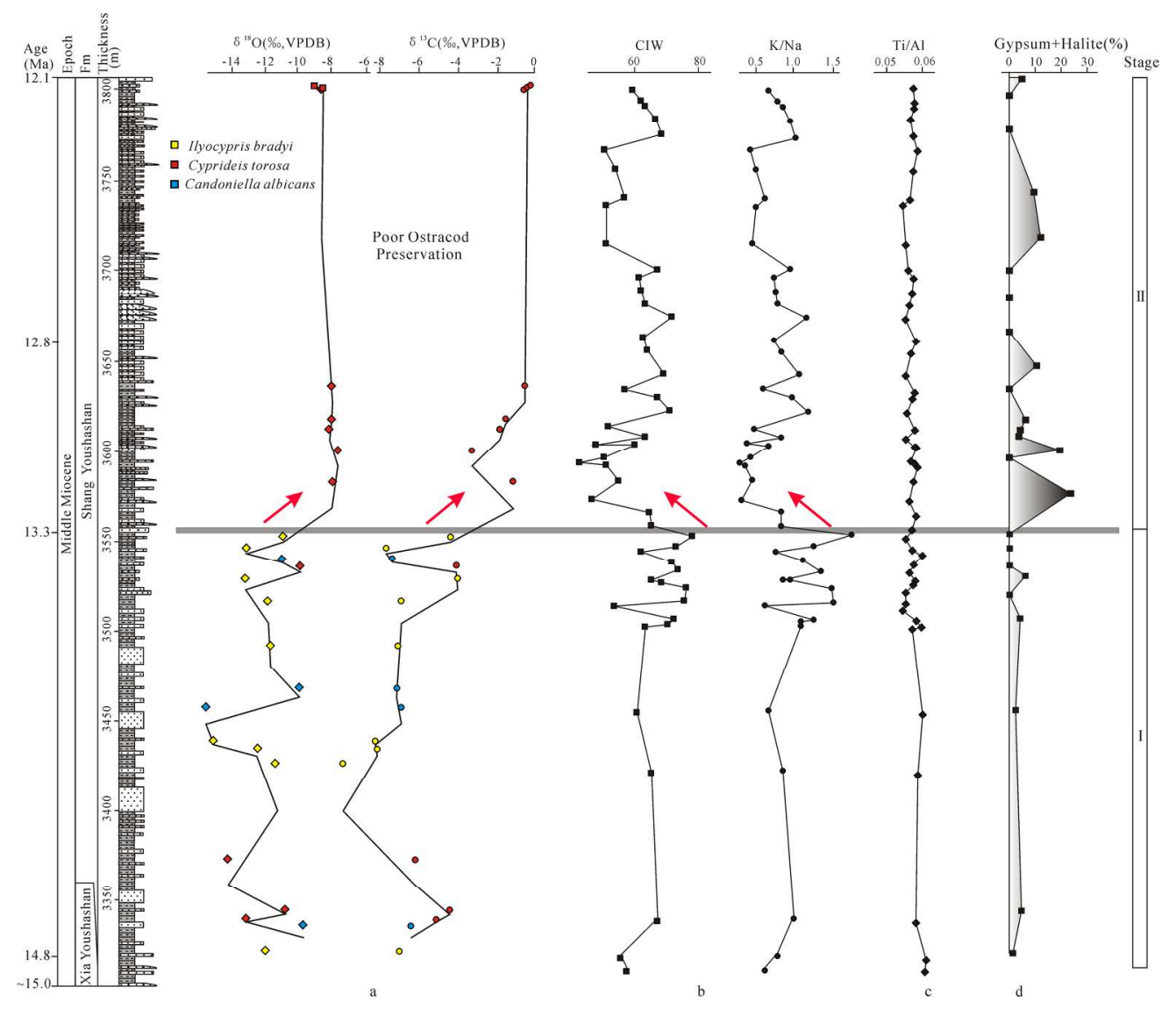

Fig 7. a. Stable isotope records $(\delta 180$ and $\delta 13 C$ ) of ostracod calcite from the sequence in the DHG section. b. vertical distribution of the CIW and K/Na ratios from the sequence in the DHG section. c. vertical distribution of Ti/AI ratios from the sequence in the DHG section. $\mathrm{d}$. vertical distribution of evaporite minerals from the sequence in the DHG section (Wang et al. 2013).

$201 \times 173 \mathrm{~mm}(300 \times 300 \mathrm{DPI})$ 


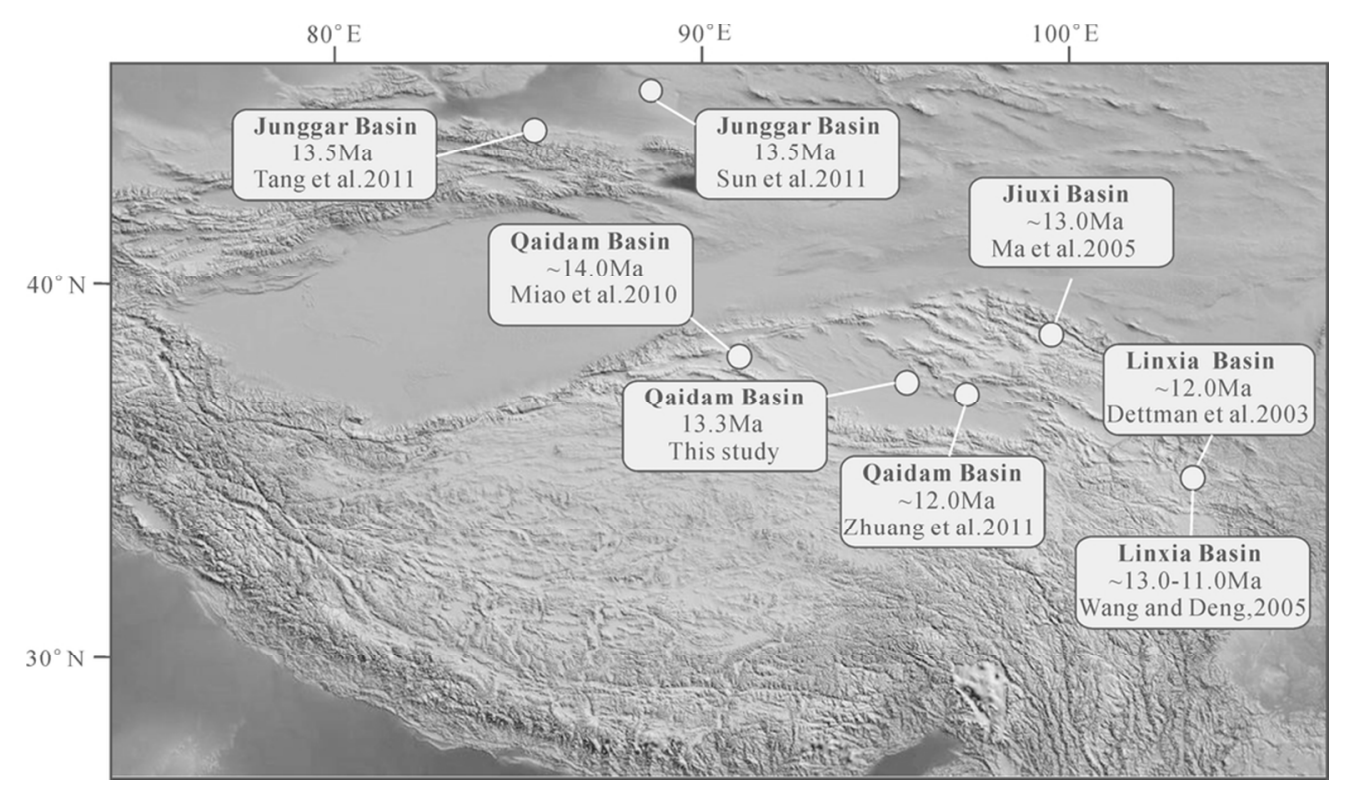

Fig 8. Map showing evidence of extensive aridification of inland Asia occurring at approximately 13 Ma.

$87 \times 50 \mathrm{~mm}(300 \times 300 \mathrm{DPI})$ 


\begin{tabular}{|c|c|c|c|c|c|c|c|c|c|c|c|c|c|c|c|c|c|c|c|}
\hline Sample Code & Preservation & 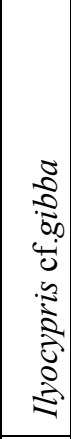 & 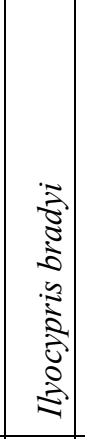 & 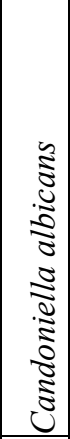 & 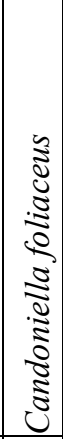 & 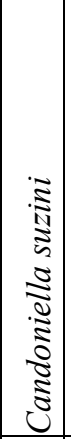 & 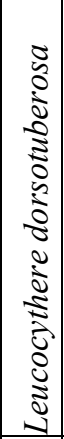 & 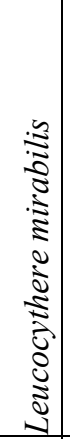 & 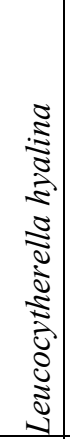 & 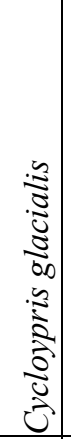 & 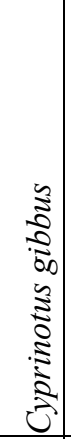 & 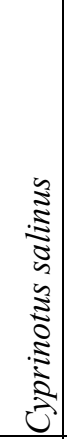 & $\mid \begin{array}{c}0 \\
0 \\
0 \\
0 \\
0 \\
0 \\
0 \\
0 \\
0 \\
0 \\
0 \\
0 \\
0 \\
\vdots \\
0 \\
0 \\
0 \\
0\end{array}$ & 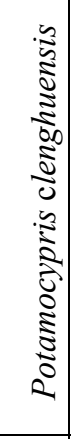 & 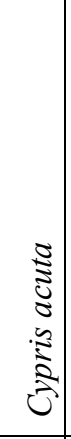 & 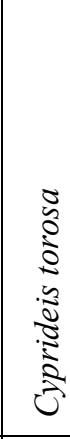 & 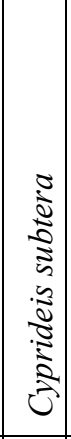 & 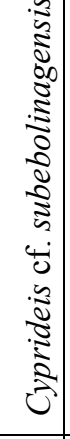 & 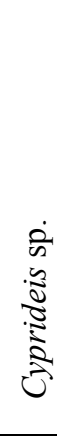 \\
\hline S27-JL335-3 & good & 13 & 48 & & & & & & & & 4 & 2 & & & 5 & 1 & & & \\
\hline S27-JL335-4 & good & 3 & 4 & & & & & & & & & & & & & & & & \\
\hline S27-JL335-5 & good & & & & & & & & & & & & & & & 1 & & & \\
\hline S27-JL335-7 & good & 49 & 157 & 15 & & & & & & & 4 & 45 & 2 & 1 & 7 & & & & \\
\hline S27-JL336-2 & good & & & & & & & & & & & & & & & 2 & & & \\
\hline S27-JL336-9 & good & 40 & 37 & & & & & & & & 1 & 1 & & & & & & & \\
\hline S27-JL336-21 & good & 8 & 37 & 1 & 2 & & 75 & & & & & 1 & & & & & & & \\
\hline S27-JL336-22 & good & 5 & 11 & & & & 16 & 3 & & & & 1 & & & & & & & \\
\hline S27-JL336-25 & good & 22 & 28 & 1 & & & & & & & & & & & & 95 & 15 & & \\
\hline S27-JL336-26 & good & & & & & & . & & & & & & & & & 31 & 2 & & \\
\hline S27-JL336-28 & good & 2 & 6 & & & & & & & & & & & & & 805 & 65 & & \\
\hline \begin{tabular}{|l|} 
S27-JL336-29 \\
\end{tabular} & good & 7 & 68 & & & & 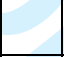 & 2 & & & & & & & & 453 & 43 & & \\
\hline \begin{tabular}{|l|} 
S27-JL336-37 \\
\end{tabular} & good & 11 & 9 & 2 & & & 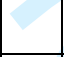 & 8 & & & & & & & & & & & \\
\hline S27-JL336-38 & good & 4 & 18 & 1 & & & & C & 2 & s & & & & & & & & & \\
\hline S27-JL336-39 & good & 11 & 50 & & & & & & r & 3 & 5 & 12 & & & 3 & 1 & & & \\
\hline S27-JL336-41 & good & 140 & 402 & & & & & & 8 & & & & & & & & & & \\
\hline S27-JL336-42 & good & & 2 & & & & & & & & & & & & & 705 & 37 & & \\
\hline S27-JL336-43 & good & 360 & 1440 & & & & & & & & & & & & & 586 & 18 & & \\
\hline S27-JL336-45 & good & & 1 & & & & & & & & & & & & & 17 & & & \\
\hline S27-JL336-48 & good & 1 & & & & & & & & & & & & & & 13 & & & \\
\hline S27-JL337-2 & good & 1 & & 1 & & & & & & & 1 & 4 & & & & & & & \\
\hline S27-JL337-3 & good & 32 & 180 & & & & & & & & & 2 & & & 2 & & & & \\
\hline S27-JL337-4 & good & 2 & 30 & & & & & & & & & 2 & & & & 2 & & & \\
\hline S27-JL337-5 & good & 95 & 1840 & & & & & & & & & 23 & & & & & & & \\
\hline S27-JL338-1 & good & & & 44 & & & & & & & & 10 & & & 2 & & & & \\
\hline S27-JL338-2 & good & 171 & 13 & 20 & 9 & 2 & 2 & & 4 & 5 & & 6 & 2 & 2 & & & & & \\
\hline S27-JL338-3 & good & 62 & 34 & 12 & & & 2 & & 9 & & & & & & & & & & \\
\hline S27-JL338-5 & good & & & 2 & & & & & & & & & & & & & & & \\
\hline S27-JL338-6 & good & 45 & 8 & 24 & & & & & & 2 & & & & & & & & & \\
\hline S27-JL338-7 & good & 28 & 2 & 110 & & & & & & & & & 2 & & & & & & \\
\hline S27-JL338-9 & good & & & 478 & 12 & 13 & & & & & 6 & 29 & & & & & & & \\
\hline S27-JL338-15 & good & 236 & 1430 & 7 & & & 15 & & & & 6 & 10 & 4 & & & & & & \\
\hline S27-JL338-17 & good & & & 20 & & 7 & & & & & & & & & & & & & \\
\hline S27-JL338-21 & good & & & 2 & & & & & & & & & & & & & & & \\
\hline
\end{tabular}




\begin{tabular}{|c|c|c|c|c|c|c|c|c|c|c|c|c|c|c|c|c|c|c|c|}
\hline Sample Code & Preservation & 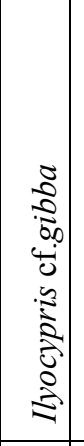 & 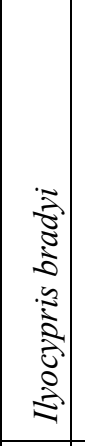 & 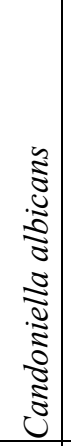 & 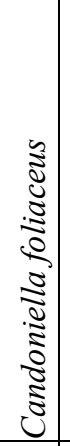 & 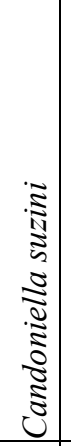 & $\begin{array}{c}0 \\
0 \\
0 \\
0 \\
0 \\
0 \\
0 \\
0 \\
0 \\
0 \\
0 \\
0 \\
0 \\
5 \\
0 \\
0 \\
0 \\
0 \\
0 \\
0\end{array}$ & 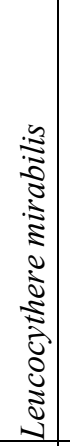 & 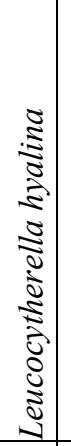 & 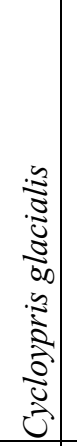 & 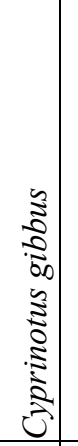 & $\begin{array}{c}0 \\
\vdots \\
\vdots \\
\vdots \\
0 \\
\vdots \\
\vdots \\
\vdots \\
\vdots \\
\vdots \\
0 \\
0\end{array}$ & $\mid \begin{array}{c}0 \\
0 \\
0 \\
0 \\
0 \\
0 \\
0 \\
5 \\
0 \\
0 \\
0 \\
0 \\
0 \\
0 \\
5 \\
0 \\
0 \\
2 \\
\end{array}$ & 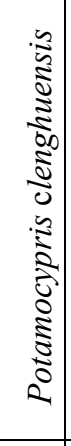 & 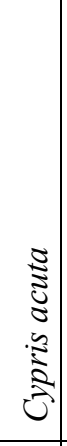 & 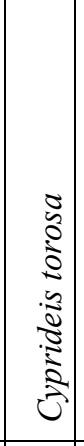 & $\left|\begin{array}{c|}0 \\
0 \\
0 \\
0 \\
0 \\
0 \\
0 \\
0 \\
0 \\
0 \\
0 \\
0\end{array}\right|$ & 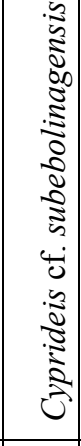 & 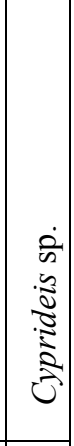 \\
\hline S27-JL340-2 & good & 5 & 22 & & & & & & 4 & & & 3 & & & & & & & \\
\hline S27-JL342-2 & good & 233 & 34 & 6 & 3 & & & & & & 5 & 6 & & & 3 & & & & \\
\hline S27-JL345-1 & good & 364 & 116 & 18 & & & 32 & 8 & 5 & & & 4 & & & & 16 & & & \\
\hline S27-JL345-2 & good & 8 & 4 & & & & 3 & & & & & & & & & & & & \\
\hline S27-JL347-3 & good & & & & & & & & & & & & & & & 454 & 30 & & \\
\hline S27-JL348-1 & good & 3 & & 35 & 12 & 18 & & & & & & 2 & 4 & 2 & & & & & \\
\hline S27-JL348-2 & good & 2 & & 16 & & 8 & & & & & & & & & & & & & \\
\hline S27-JL349-1 & good & 230 & 64 & & & & 4 & & & & & & & & & & & & \\
\hline S27-JL350-1 & good & 1115 & 258 & 16 & & & 75 & 17 & & & 5 & 12 & 8 & & 4 & & & & \\
\hline S27-JL351-2 & good & 6 & & & & & 3 & & & & & & & & & & & & \\
\hline S27-JL355-1 & good & & & & & & & & & & & & & & & 63 & 6 & & \\
\hline S27-JL359-3 & good & & & & & & 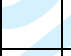 & - & & & & & & & & 52 & 8 & & \\
\hline S27-JL362-1 & good & & & & & & 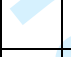 & & & & & & & & 2 & 54 & & 5 & 9 \\
\hline S27-JL362-3 & good & & & & & & & & 2 & D & & & & & & 18 & & & 9 \\
\hline S27-JL363-1 & good & & & & & & & & 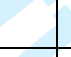 & 3 & & & & & 24 & 52 & & 6 & 370 \\
\hline S27-JL363-3 & good & & & & & & & & 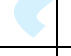 & & & & & & 46 & 224 & & 4 & 89 \\
\hline S27-JL363-5 & good & & & & & & & & & & & & & & 3 & 44 & & & 19 \\
\hline S27-JL363-6 & good & & & & & & & & & & & & & & 12 & 114 & & 3 & 34 \\
\hline S27-JL365-1 & good & & & & & & & & & & & & & & & 57 & & 3 & 12 \\
\hline S27-JL385-1 & good & & & & & & & & & & & & & & & 88 & 14 & 8 & \\
\hline S27-JL385-3 & good & & & & & & & & & & & & & & & 1690 & 146 & 45 & \\
\hline S27-JL385-6 & good & & & & & & & & & & & & & & & 420 & 44 & 18 & \\
\hline S27-JL386-1 & good & & & & & & & & & & & & & & & 346 & 26 & 16 & \\
\hline
\end{tabular}

